ENTREPRENEURSHIP AND SUSTAINABILITY ISSUES

ISSN 2345-0282 (online) http://jssidoi.org/jesi/

2019 Volume 7 Number 2 (December)

http://doi.org/10.9770/jesi.2019.7.2(63)

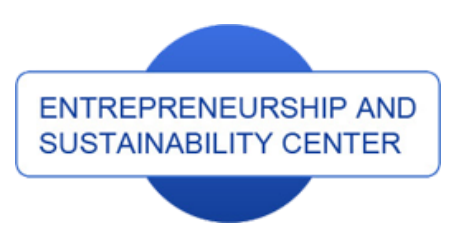

Publisher

http://jssidoi.org/esc/home

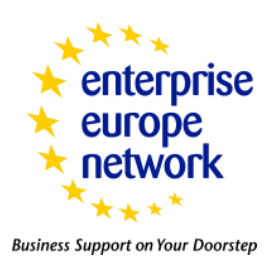

CASPA

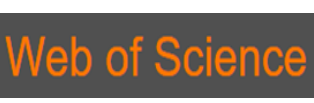

1) Clarivate

\title{
THE ROLE OF SPENDING ON EDUCATION AND SCIENCE IN SUSTAINABLE DEVELOPMENT
}

\author{
Sugra Ingilab Humbatova ${ }^{1}$, Natig Gadim-Oglu Hajiyev ${ }^{2 *}$ \\ ${ }^{1}$ Department "Economy and Managements", Azerbaijan State University of Economics (UNEC), Istiqlaliyyat Str. 6, Baku, \\ AZ-1001, Azerbaijan \\ ${ }^{1}$ Department “World Economy”, Baku Engineering University (BEU), Hasan Aliyev str., 120. Khirdalan, AZ-0102, \\ Absheron, Azerbaijan \\ ${ }^{2}$ Department "Regulation of economy", Azerbaijan State University of Economics (UNEC), Istiqlaliyyat Str. 6, Baku, \\ AZ-1001, Azerbaijan
}

\begin{abstract}
E-mails ${ }^{l}$ :sugra_humbatova@unec.edu.az; ${ }^{2 *}$ n.qadjiev2012@yandex.ru; naig_hajivev@unec.edu.az
(Corresponding author)
\end{abstract}

Received 17 August 2019; accepted 27 November 2019; published 15 December 2019.

\begin{abstract}
Azerbaijan is an exporter country of natural resources (oil). Since the main power of modern economy including the future economic progress is human factor, human capital, its knowledge, ability of using technology, transferring oil capital into human capital is a driving factor. That's why researching the influence of the main indicators of education and state budget allocations for it is a topical issue. The article has researched the relationship of state budget allocation and the main indicators of education and science during 21 years (1996-2017) in the Restate of Azerbaijan. Auto Regressive Distributed Lags has been used as a research model. Besides, stationary tests of variables (Augmented Dickey Fuller, Phillips-Perron, Kwiatkowski-Phillips-Schmidt-Shin) and Pairwise Granger Causality Tests were used. Model stability was studied. Eviews_9 software program was applied for making graphics and calculations. Research has examined that there is a positive dependency between state budget allocation and the main indicators of education. We recommend that state budget allocation for science and education can be increased and used as the intended purpose.
\end{abstract}

Keywords: education; science; spending; sustainable development; ARDL

Reference to this paper should be made as follows: Humbatova, S.I., Gadim-Oglu Hajiyev, N. 2019. The role of spending on education and science in sustainable development. Entrepreneurship and Sustainability Issues, 7(2), 1704-1727. http://doi.org/10.9770/jesi.2019.7.2(63)

JEL Classifications: I22, I25

\section{Introduction}

Human capital is the main resource in economy. The increasing role of human capital is related with geometric sequence rather than arithmetic sequence of events and processes. The 50-60s rapid development is related with the development of technologies, especially information and communication technologies and their employment 


\section{ENTREPRENEURSHIP AND SUSTAINABILITY ISSUES}

ISSN 2345-0282 (online) http://jssidoi.org/jesi/

2019 Volume 7 Number 2 (December)

http://doi.org/10.9770/jesi.2019.7.2(63)

on production spheres. And the human capital plays important role for all of these. All these achievements are related with knowledge, science and education.

Nowadays, scientific and intellectual potential has become an important factor in the development of our country (İbrahimov et al. 2019). Providing a reliable guarantee to the rapid economic development and to progressive reforms in all spheres of state life is important in Azerbaijan recently. The reforms that we meet the requirements of new stage of development has implemented in a systematic way and has shown the effectiveness of the policy that calculated on the basis of the objective of a strong human capital formation. Today, science and education serve not only to the cultural development of society and to improve the living conditions and welfare of people but also to prevent the negative tendencies, acts of primitive thinking causing the eradication of social institutions since ancient times almost without administrative intervention. If we don't consider the achievements of science and education, the facts itself show that countries with high levels of science and education witness fewer criminal cases.

If today the vector of global thinking focuses on building a civil society and observes the peak of human development for it can only be achieved by applying scientific achievements and enhancing the intellectual level of people. The restoration of social justice, the rise of material and moral values, and the global economic development are the only factors. Therefore, some kind of competition has already begun for this purpose among 200 countries of the world. The state policy pursued in Azerbaijan is based on this direction. Transition of Azerbaijan's existing economic potential into intellectual wealth - human capital - has been declared the main strategic course. A lot of important work is being done in this area too. This trend towards the development of science and education, as well as the development course in this field, is now accompanied by greater achievements. In this regard, state programs have been adopted, which are aimed at integrating into the world of science and education, and steps towards these goals are consistent.

\subsection{Hypotheses}

Hypotheses:

- science and education are the main factors of economic development (sustainability);

- macroeconomic indicators of science and education are directly dependent on funding;

- diversification of funding for science and education has a positive impact on sustainable development.

\section{Literature review}

\subsection{Science, education and sustainable development}

The agenda of UNO XXI conference (1998) states that education plays an essential role for our future prosperity. Since then, education has been the main focus of the purpose, essence and terminology of sustainable development (Sjöström, Rauch \& Eilks, 2015). It must be noted that sustainability was formed in forestry in XVI century in Europe (Burmeister et al. 2012).

Undoubtedly, science and technology is the basis for economic sustainable development of each industrialised society (Bradley 2005; Ware, 2001). Although science and technology is a leading factor, education is considered one of the main attributes of sustainable development as well (Bradley 2005). Gough Stephen and William Scott researched the Great Britain education system and summarized that education has been under state control for 150 years and included sustainable development plan since 1992 (Gough \& Scott, 2006).

Inarguable, science is one of the bases of sustainable development. Sustainability problem and the bases of science changes regularly in the world (Humbatova \& Abidi, 2019). Not only does knowledge and science 


\section{ENTREPRENEURSHIP AND SUSTAINABILITY ISSUES}

ISSN 2345-0282 (online) http://jssidoi.org/jesi/

2019 Volume 7 Number 2 (December)

http://doi.org/10.9770/jesi.2019.7.2(63)

contribute to ignore difficulties, but also it supports innovation and draws young talents attention for sustainability problem (Wilbanks \& Thomas 2010).

There has been a growing interest to high education for sustainable development (the growing number of scientists, academicians and students) in the last 20 years (Hallinger \& Chatchai, 2019). Hallinger and Chatpinyakoop analysed that $64 \%$ of scientific researches concerning HESD have occurred in the last 5 years (2013-2018). This tendency proves that scientists are interested in HESD (Hallinger \& Chatchai, 2019). Science and technological potential and education are undeniable factors to solve problems related to regional sustainable development (Keane \& Allison, 1999) and ecology (Zilahyg \& Huisingh, 2009). Universities significantly impact on regional sustainable development (Arbo \& Benneworth, 2007; Stephens et al., 2008; Wals, 2009). Higher education plays an important role in sustainable development in global scale (Yuan \& Zuo, 2013; Hien \& Cho, 2018; Girdzijauskaite et al., 2019).

Higher education is an igniting factor for sustainable development (Holbrook, 2009). Among different entities, universities take a great role in sustainable development context (Cortese, 2003; Fien, 2002). Education for sustainable development is a political purpose and a good notion from education point of view (Burmeister, Rauch \& Eilks, 2012). However, the biggest contribution of education to business, state and society is to prepare specialists for this purpose (Chalkley, 2006; Wals, 2013).

Angely V. Malenkiy, Endy Green researched the role of education in globalisation and its relationship with sustainable development in China, India, Kenya and Sri Lanka (Little, \& Green 2009). Elein Nevin examined the mutual relationships between education and sustainable development as well as with ecology in Ireland (Nevin, 2008). CIS economists have also researched education, science and sustainable development problems (Muradov, Hasanli \& Hajiyev, 2019; Muradov, Hasanli \& Musayeva, 2019; Mukhtarov et al., 2019).

\subsection{Science, education and economic growth}

Liu and Bi has researched the influence of production factors on higher education (Liu \& Bi, 2019) and Crespo has examined the role of education with sustainable development (Bárbara et al., 2017).

Although some economists give a positive feedback about the influence of education on economic growth and development (Tvaronavičienė, Tarkhanova \& Durglishvili, 2018; Tvaronavičienè et al., 2017), some others prove the opposite (Wolff, 2001; Vedder. 2004; Hanushek, 2016; Sun, Ning \& University, 2016).

Zhou and Luo researched the mutual relationship of technological innovation with higher education in China through VAR method in 1997-2015 (Zhou \& Luo, 2018). On the other hand, mutual relations of education and employment rate, trade and economic growth in Pakistan (Butt \& Hassan, 2008; Hassan \& Butt, 2009), and the impact of education on production factors and productivity in Nepal (Dahal, 2015) were studied.

They proposed that municipalities must play a crucial role for the preparation of regional programs. The distribution of resources and finance among regions will stimulate the formation of human capital. In other words, the formation of human resources differes depending on the regional features. Besides, the role of economic growth on science has been in the centre. Wang and Huang researched empiric analysis the mutual relations of science and technology and economic growth in agriculture (Tianqi \& Lijun, 2018).

Slottje (2010) was inspired by the importance of human capital development on economic growth so that this fact has played as a motivation factor for the research. Lyakurwa (2019) proved that human capital development improves knowledge and habits of human capital and as a result, it increases GDP. 


\section{ENTREPRENEURSHIP AND SUSTAINABILITY ISSUES}

ISSN 2345-0282 (online) http://jssidoi.org/jesi/

2019 Volume 7 Number 2 (December)

http://doi.org/10.9770/jesi.2019.7.2(63)

In another research, it has been proved there is a positive correlation between educational entities and labour market. Thus, a good specialist acts as a basis of economic development (Ahmed \& Liu, 2019).

\subsection{Finance of education and science}

Finance and expenses of education and science has been in the centre of attention of scientists. Resnik researched the important aspects of finance and economics for science (Resnik, 2007). Besides Resnik, some scientist has touched a burning issues such as the influence of R\&D finance on scientific productivity (Jacob \& Lefgren,2011), the influence of state finance contracts on scientific productivity in Spain (Alonso-Borrego, Romero-Medina \& Sánchez-Mangas, 2017), the importance of state policy of R\&D works for engineers and scientists in the USA (Goolsbee, 1998), the connection between financeial sources for science and scientific articles (Lesser et al., 2007), the influence of allocated investment by Congress on the development of universities (Payne \& Siow, 2003), bibliometric analysis of scientific works financed by South Africa (Albrecht, 2014), the influence of financial resources on the development of science in the USA (Whalley \& Hicks, 2014) and the usage of scientific articles for evaluation of R\&D expenses in the USA (Wagner, 1996).

The impact of state academic researches and financial sources on R\&D (Goldfarb, 2008), the assessment of finance on science (Lane, 2009), the real effects of academic researches on R\&D works of universities and commercial entities (Adam, 1989), the role of economics on the formation of science (Stephan, 2012), the influence of state education expences on the increase of GDP per person in Tunisia and Marocco (Adel, \& Guetat, 2018) have been researched.

Lamartina and Zaghini (2011) examined state expenses role in economic growth in 23 OECD countries and concluded that there is a positive correlation between state public expenses (education, helath etc) and GDP per person. Thus, the increase of expenses concerning human capital causes GDP per person. Besides, Ogujiuba and Adeniyi (Ogujiuba \& Adeniyi, 2005) researched the influence of state expenses on education in Nigeria. The relations between current expenses of education and economic growth are statistically significance. However, this relation is not observed for the investment on education.

Summarizing the literature review, research on this topic is not sufficient. Thus, public and private expenses on education and science, especially the influence of science and education on economic indicators is still new.

\section{Data and methods}

\subsection{Data}

Statistical data encompasses 1995-2017. Data have been taken from Statistics Committee of the Republic of Azerbaijan.

\begin{tabular}{|c|c|c|c|c|c|c|c|c|c|c|c|c|}
\hline Year & $\begin{array}{l}\text { The } \\
\text { number of } \\
\text { students at } \\
\text { the higher } \\
\text { education } \\
\text { institutions } \\
\text { - total, } \\
\text { person }\end{array}$ & $\begin{array}{c}\text { The } \\
\text { number of } \\
\text { master } \\
\text { students at } \\
\text { the higher } \\
\text { education } \\
\text { institutions } \\
\text { (admission) } \\
\text { - total, } \\
\text { person }\end{array}$ & $\begin{array}{c}\text { The } \\
\text { number of } \\
\text { bachelor } \\
\text { students at } \\
\text { the higher } \\
\text { education } \\
\text { institutions } \\
\text { (admission) } \\
\text { - total, } \\
\text { person }\end{array}$ & $\begin{array}{c}\text { The } \\
\text { number of } \\
\text { graduated } \\
\text { students at } \\
\text { the higher } \\
\text { education } \\
\text { institutions } \\
\text { - total, } \\
\text { person }\end{array}$ & $\begin{array}{c}\text { The } \\
\text { number } \\
\text { of Phd } \\
\text { students } \\
- \\
\text { person }\end{array}$ & $\begin{array}{l}\text { Admis- } \\
\text { sion to } \\
\text { Phd } \\
\text { programs } \\
\text { - person }\end{array}$ & $\begin{array}{c}\text { The } \\
\text { number } \\
\text { of } \\
\text { graduated } \\
\text { Phd } \\
\text { students, } \\
\text { person }\end{array}$ & $\begin{array}{c}\text { The } \\
\text { number } \\
\text { of } \\
\text { institutio } \\
\text { ns for } \\
\text { doctorate } \\
\text { degree }\end{array}$ & $\begin{array}{c}\text { The } \\
\text { number } \\
\text { of } \\
\text { students } \\
\text { on } \\
\text { doctorate } \\
\text { degree } \\
\text { program } \\
\text { - person }\end{array}$ & $\begin{array}{l}\text { The } \\
\text { admis- } \\
\text { sion to } \\
\text { doctorat } \\
\mathrm{e} \\
\text { degree } \\
\text { progra } \\
\mathrm{m}- \\
\text { person }\end{array}$ & $\begin{array}{l}\text { The } \\
\text { number } \\
\text { of } \\
\text { doctorate } \\
\text { degree } \\
\text { graduate } \\
\text { students } \\
\text { - person }\end{array}$ & $\begin{array}{c}\text { Budget } \\
\text { expenses } \\
\text { (educatio } \\
\text { n and } \\
\text { science) } \\
\text { - mln.ma } \\
\text { nat }\end{array}$ \\
\hline 1996 & 102742 & 1795 & 22127 & 19377 & 1306 & 386 & 307 & 23 & 65 & 19 & 6 & 524671 \\
\hline 1997 & 100180 & 1877 & 23487 & 24274 & 1347 & 303 & 274 & 19 & 78 & 19 & 6 & 689482 \\
\hline 1998 & 106482 & 1991 & 26817 & 21113 & 1218 & 253 & 368 & 25 & 83 & 23 & 18 & 870840 \\
\hline
\end{tabular}




\section{ENTREPRENEURSHIP AND SUSTAINABILITY ISSUES}

ISSN 2345-0282 (online) http://jssidoi.org/jesi/ 2019 Volume 7 Number 2 (December) http://doi.org/10.9770/jesi.2019.7.2(63)

\begin{tabular}{|c|c|c|c|c|c|c|c|c|c|c|c|c|}
\hline 1999 & 116115 & 2544 & 24605 & 20030 & 907 & 151 & 418 & 23 & 55 & 10 & 36 & 903591 \\
\hline 2000 & 119683 & 2752 & 26403 & 24488 & 963 & 367 & 321 & 21 & 47 & 9 & 22 & 1006196 \\
\hline 2001 & 120453 & 3390 & 26944 & 23903 & 982 & 292 & 244 & 16 & 40 & 17 & 7 & 1069655 \\
\hline 2002 & 120039 & 3827 & 19681 & 27795 & 1059 & 303 & 202 & 17 & 58 & 18 & 7 & 1013345 \\
\hline 2003 & 121535 & 4470 & 25438 & 28460 & 1178 & 398 & 260 & 19 & 57 & 14 & 15 & 1305812 \\
\hline 2004 & 127248 & 5455 & 26988 & 31232 & 1318 & 470 & 320 & 20 & 68 & 14 & 6 & 1641415 \\
\hline 2005 & 129948 & 3236 & 28747 & 32508 & 1479 & 503 & 317 & 21 & 80 & 18 & 8 & 2037197 \\
\hline 2006 & 129141 & 2757 & 23873 & 28141 & 1705 & 550 & 340 & 19 & 80 & 17 & 11 & $5,33 \mathrm{E}+08$ \\
\hline 2007 & 130430 & 3404 & 25846 & 31279 & 1681 & 452 & 431 & 24 & 83 & 19 & 20 & $7,76 \mathrm{E}+08$ \\
\hline 2008 & 136587 & 3265 & 28765 & 32580 & 1636 & 455 & 503 & 31 & 93 & 22 & 25 & $1,04 \mathrm{E}+09$ \\
\hline 2009 & 139194 & 3934 & 29822 & 34591 & 1084 & 51 & 593 & 32 & 64 & 20 & 43 & $1,23 \mathrm{E}+09$ \\
\hline 2010 & 140241 & 3698 & 29904 & 31071 & 786 & 5 & 455 & 26 & 91 & 13 & 13 & $1,27 \mathrm{E}+09$ \\
\hline 2011 & 143146 & 4225 & 31212 & 30812 & 897 & 677 & 396 & 74 & 185 & 168 & 10 & $1,37 \mathrm{E}+09$ \\
\hline 2012 & 145584 & 4746 & 33327 & 35128 & 1601 & 814 & 232 & 74 & 411 & 219 & 44 & $1,57 \mathrm{E}+09$ \\
\hline 2013 & 151274 & 5514 & 35370 & 33758 & 2070 & 625 & 131 & 74 & 426 & 134 & 7 & $1,66 \mathrm{E}+09$ \\
\hline 2014 & 158212 & 4913 & 35801 & 32826 & 2400 & 629 & 377 & 64 & 535 & 129 & 50 & $1,8 \mathrm{E}+09$ \\
\hline 2015 & 161234 & 4953 & 33645 & 33705 & 2282 & 558 & 636 & 78 & 593 & 94 & 66 & $1,72 \mathrm{E}+09$ \\
\hline 2016 & 163779 & 5098 & 36126 & 36951 & 2182 & 420 & 543 & 77 & 541 & 101 & 79 & $1,86 \mathrm{E}+09$ \\
\hline 2017 & 167677 & 6515 & 38546 & 37506 & 2168 & 455 & 529 & 88 & 555 & 129 & 69 & $1,85 \mathrm{E}+09$ \\
\hline
\end{tabular}

Note: www.stat.gov.az

\subsection{ARDL method}

Cointegrated ARDL method is as developed by Pesaran and others (Pesaran, Smith \& Shin, 2001). However, this method has a number of advantages comparing previous cointegration methods (Pesaran \& Shin, 1999; Oteng-Abayie \& Frimpong, 2006). This sample yields more reliable results when there are a few of them. Meanwhile, Ordinary Least Squares (OLS) method must be used for assessment. However, there is no endogenic problems in ARDL econometric modelling. Thus, it is possible to assess short and long-term coefficients within one model. We can calculate not differing the variables whether there are I(0) or I(I) or mixed in ARDL model (Frimpong \& Oteng-Abayie, 2006; Sulaiman \& Muhammad, 2010). Obviously, while I(0) and I(1) are used, series variables are known to what extent they are stationary and are defined by the single root test (ADF, PP, KPSS). ARDL assessments contain of the below-mentioned steps. 1) Unlimited Error Correction Model (UECM) is established. The mathematical expression of the model is as the following:

$$
\begin{aligned}
& \Delta Y_{t}=a_{y}+\sum_{i=1}^{n} \beta_{y i} \Delta Y_{t-i}+\sum_{j=0}^{n} \gamma_{y i} \Delta X_{t-J}+\theta_{y 1} Y_{t-1}+\theta_{y 2} X_{t-1}+\varepsilon_{y t} \\
& \Delta X_{t}=a_{x}+\sum_{i=1}^{n} \beta_{x i} \Delta X_{t-i}+\sum_{j=0}^{n} \gamma_{x i} \Delta Y_{t-J}+\theta_{x 1} X_{t-1}+\theta_{x 2} Y_{t-1}+\varepsilon_{x t}
\end{aligned}
$$

In equation 1 and 2 two-variable ECM structure (one dependent and one indidependent) was indicated. Y and X are both independent and dependent variables interchangably. $a$ Indicates independent limit of the model and $\varepsilon$ shows white noise error. $\theta_{i}$ is for long-term coefficient, $\beta_{i}$ and $\gamma_{i}$ is for short term coefficients.

2) Having established ECM in ARDL, the existence of cointegration relationships between variables are checked. For this, zero hypothesis is checked through Wald test (or $F$ test) on $\theta_{\mathrm{I}}$ for a long-term coefficient $\left(H_{0}: \theta=\theta_{y}=\theta_{x}=\cdots 0\right)$. The alternative hypothesis proposed is the existence of cointegration analysis among variables $\left(H_{1}: \theta \neq \theta_{y} \neq \theta_{x} \neq \cdots 0\right)$.

The existence of cointegration relations is defined by zero hypotheses. Once the existence of cointegration analysis is proved, the stability of this relationship is checked. If $y_{\mathrm{t}-1}$ coefficient is $\theta$ statistically important and negative, then cointegration relation is stable. It means that deviations from unbalanced situation and long-term 
relations are temporary and it is getting corrected towards long term relations. $\theta$ is expected to be at -1 and 0 level.

3) If the existence of the cointegration relations is proved, we can assess long term period coefficients in the next step. That's why, we can apply Bewley (1979) transformation by equalizing long-term coefficients to 0 in equation $1\left(a_{x}+\theta y_{t-1}+\theta_{y x} x_{t-1}=0\right)$, and we can solve it in terms of $y$ :

$$
y_{t}=-\frac{a_{x}}{\theta}-\frac{\theta_{y x}}{\theta} x_{t}+\varepsilon_{t}
$$

4) In this phase, long-term white noise error $\left(E C T_{t}\right)$ is calculated and inserted into the equation instead of long-term coefficients $\left(\theta y_{t-1}+\theta_{y x} x_{t-1}\right)$. Subsequently, assessment is done and the stability of cointegration relations is checked again. The mathematical function of evaluating model is as the following:

$$
\begin{aligned}
& \Delta Y_{t}=a_{y}+\sum_{i=1}^{n} \beta_{y i} \Delta Y_{t-i}+\sum_{j=0}^{n} \gamma_{y i} \Delta X_{t-J}+\mu E C T_{t-1}+\varepsilon_{y t} \\
& E C T_{t-1}=-\frac{a_{x}}{\theta}-\frac{\theta_{y x}}{\theta} x_{t} \\
& \Delta X_{t}=a_{x}+\sum_{i=1}^{n} \beta_{x i} \Delta X_{t-i}+\sum_{j=0}^{n} \gamma_{x i} \Delta Y_{t-J}+\mu E C T_{t-1}+\varepsilon_{x t} \\
& E C T_{t-1}=-\frac{a_{y}}{\theta}-\frac{\theta_{y x}}{\theta} y_{t}
\end{aligned}
$$

So, $y_{t}$ or $x_{t}$ is true value of dependent variable. $\left(-\frac{a_{x}}{A}-\frac{\theta_{y x}}{A} x_{t}\right)$ is calculated value according to long-term equation (equation 1 and 2). In equation 4 and 6 , if $\mu$ is between -1 and 0 and statistically important, then the cointegration realtions are constant. As mentioned above, deviation for short term period is inclined to be corrected towards long term relation. In case any serious calculation error is not noted, $\mu$ is getting close to $\theta$ coefficient in equation 1 and 2 , sometimes gets equal value. So, the last phase is also considered as monitoring.

\subsection{Engel-Granger (EG) cointegration test}

Additionally, Engel-Granger (EG) cointegration test is used to check the cointegration relations among variables during econometric analysis. Beside the existence of long-term relations, it is possible to identify the direction of the relation among variables and research short-term relations (Nadirov \& Aliyev, 2016). EG cointegration test consists of the following criteria (Gujarati \& Porter, 2009; Enders, 2010). At the first phase, regression analysis for non-original stationary but the same-level differentiated stationary (I(1)) variables is assessed. So, for the case of two variables:

$$
y_{t}=\alpha_{0}+\alpha_{1} x_{t}+\varepsilon_{t}
$$

Thus, $\alpha_{0}$ and $\alpha_{1}$ - regression coefficients, $y$ and $x$-dependent and independent variables, $\varepsilon-$ white noise error, $t$ - time. Having assessed regsression analysis, the next phase is to check whether $\varepsilon$ is white noise error. If $\varepsilon_{t}$ is stationary, there will be cointegration relations among these variables. Accordingly, it will be considered as long-term equations. At the last phase, ECM is assessed by using delayed white noise error $\left(\varepsilon_{t-1}\right)$ and converting cause-effect relations into stationary one. 


\section{ENTREPRENEURSHIP AND SUSTAINABILITY ISSUES}

ISSN 2345-0282 (online) http://jssidoi.org/jesi/

2019 Volume 7 Number 2 (December)

http://doi.org/10.9770/jesi.2019.7.2(63)

$$
\Delta Y_{t}=a_{y}+\sum_{i=1}^{n} \beta_{y i} \Delta Y_{t-i}+\sum_{j=0}^{n} \gamma_{y i} \Delta X_{t-J}+\mu E C T_{t-1}+\varepsilon_{y t}
$$

Thus, $a_{y}, \beta_{y i}, \gamma_{y i}$ and $\mu$ coefficiants are mentioned. $n$ is a optimum delayed measure and $\varepsilon$ is a white noise error of the model. In order to identify optimum delayed measure, first we have to assess Vector Autoregressive (VAR) model among variables. Then, the equation 9 is assessed considering optimum delayed measure through the Least Square Method (LSM). Engle and Granger (1987) shows that if there is the existence of cointegration among variables, ECM assessment is a must. In case of having constant cointegration relations, Error Correction Term ECT, thus $E C T_{t-1}$ coefficient $\mu$ is negative and statistically important. Usually, this changes -1 and 0 . If it is greater than -1 , this correction process is going to be high. Using through equation 9 , we can check cause-effect relations.

Granger cause-effect relation for a short term is assessed by using $\mathrm{F}$-statistics and $\mathrm{X}$ square statistics value. This time, the statistical importance of all delay differential equation (all $\Delta X_{t-I}$ ) for each variable (zero hypothesis: $\left.H_{0}: \gamma_{y 1}=\gamma_{y 2}=\cdots=\gamma_{y i}=0, i=1 \ldots n\right)$ is checked. Having zero hypothesis rejected, we can see that $x$ has influence on $y$ for a short term.

For a long term, Granger use $t$ test to identify cause-effect relations and check the statistically importance of $E C T_{t-1}$ coefficient. Therefore, zero hypothesis $\left(H_{0}: \mu=0\right)$ is needed to be tested. If zero hypothesis is rejected at the end, ti will reveal that there is a long-term balance impact on it and it will normalize after a while.

Strong cause-effect relation serves to check the relations both in short- and long-term periods. In other words, through Wald test, $F$-statistics or $X_{i}$-square statistic value is checked as a zero hypothesis for each sample variable (zero hipothesis: $H_{0}: \gamma_{y 1}=\gamma_{y 2}=\cdots=\gamma_{y i}=\mu=0, i=1 \ldots n$ ).

\subsection{Unit Root tests}

It is essential to check the stationary of variables through Unit Root before the assessment of regression equations. Because, keeping stability between variables is important while assessing the dependency between two or more variables by using regression analysis. However, probability distribution for every time series in order to be stationary must be identical (Hasanov et al., 2019). Nevertheless, stationary of variables is not always desirable. For a long term or cointegration relation and assessment, the variables must be non-stationary in most methods. It is also required that the first difference should be stationary or I(1). It must be noted that if any time series variable is stationary with real values, then it can be considered $\mathrm{I}(0)$. If a variable is not $\mathrm{I}(0)$, then its first difference is calculated and its stationary is checked. In this case, if the variable is stationary, then it is considered I(1). A variable sometimes changes because of probability distribution. In that case, the variable becomes trend-stationary. One can refer to modern econometric books regarding the stationary of changes and its effect in time series analysis (Hill, Griffiths \& Judge, 2001; Heij et. al., 2005; Asteriou \& Hall, 2007). We can analyze them by applying three different unit root tests in order to get more reliable stationary test results: Augmented Dickey Fuller, Phillips-Perron (PP) and Kwiatkowski-Phillips-Schmidt-Shin (KPSS). The evaluation of these tests is done through E-Views 9. It must be noted that "unit root problem" or "variable is non-stationary" null hypothesis in unit root tests is checked. In KPSS test, "variable is stationary" hypothesis is taken and considered as stationary null hypothesis. If the variable is non-stationary without trend, and becomes stationary if trend is included, then the checked variable is considered "trend-stationary". 


\subsection{VAR Lag Order Selection Criteria}

\subsection{The Long Run Model}

$$
Y_{t}=\alpha+\sum_{i=1}^{n-1} \varphi_{i} \Delta Y_{t-i}+\sum_{i=0}^{m-1} \rho_{i} \Delta X_{t-i}+\mu_{i}
$$

\subsection{Error Correction (short run) Model}

$$
\Delta Y_{t}=\alpha+\sum_{i=1}^{n-1} \varphi_{i} \Delta Y_{t-i}+\sum_{i=0}^{m-1} \rho_{i} \Delta X_{t-i}+\sigma E C T_{t-1}+\omega_{i}
$$

\subsection{Diagnostic Test}

This article will use Breusch Godfrey LM test (null hypothesis: "no serial correlation") in order to check subsequent correlation problem and use both Breusch-Pagan-Godfrey (null hypothesis: "no heteroskedasticity problem") and Autoregressive Conditional Hederoscedasticity test (ARCH) for obtaining more reliable outcomes for heteroskedasticity problem. During ARCH test, null hypothesis "no heteroskedasticity problem" theory is checked. Nonetheless, Ramsey RESET Test and Normality Test (Jarque-Bera) JB was checked. Null hypothesis rejection is acceptable for every five cases.

\section{Results}

\subsection{Unit Root Test}

Let's have a look at stationary of variables before identifying methods for evaluation. All stationary test results of variables for evaluation of both problems were given in the table. Each variable has been checked through three different unit root tests. The table shows that the majority of variables are I(1).

Thus, according to ADF test, in With Intercept only case, APHDS GFHDS are stationary. (I(0)). The rest of the variables are stationary I(1). In With Intercept \& Trend case BSHEIT GSHEIT GFHDS and DDGS I(0) The rest of the variables are stationary I(1). In No Intercept \& No Trend case, SHEIBMT I(2) is stationary again. The rest of the variables are stationary I(1) (A.Table 1).

In PP Unit Root Test, in With Intercept only case, APHDS I(0) are stationary. The rest of the variables are stationary I(1). In With Intercept \& Trend case, BSHEIT GSHEIT and DDGS I(0) PHDS I(2) are stationary. The rest of the variables are stationary I(1). In No Intercept \& No Trend case only BSHEIT I(2) is stationary. The rest of the variables are stationary I(I) (A.Table 2).

According to Kwiatkowski-Phillips-Schmidt-Shin test statistics most of the variables are I(0) (A.Table 3).

All these results are available for next assessment and methods. Reliant on the enumerated test results, variable are accepted as I(1). It means that all above-mentioned methods are applicable. As mentioned above, during application process of ARDL cointegration method, one of the important issues while establishing a model is to identify optimum lag length. At this time, the most important factor is to eliminate the subsequent correlation problem in selected optimum model and keep the minimum of SBC information criteria value. 


\subsection{VAR Lag Order Selection Criteria}

In order to determine optimal lag for ARDL model, VAR Lag Order Selection Criteria was employed and we got the below-mentioned results.

Table 2. VAR Lag Order Selection Criteria

\begin{tabular}{|c|c|c|c|}
\hline & Lag & AIC & SC \\
\hline LSHEIBMT & 1 & $-1.150803^{*}$ & $-0.852368^{*}$ \\
\hline LMSHEIT & 1 & $2.678722^{*}$ & $2.977157^{*}$ \\
\hline LBSHEIT & 1 & $1.574041^{*}$ & $1.872476^{*}$ \\
\hline LGSHEIT & 1 & $1.241935^{*}$ & $1.540370^{*}$ \\
\hline LPHDS & 1 & $3.159086^{*}$ & $3.457521^{*}$ \\
\hline LAPHDS & 1 & $6.575382^{*}$ & $6.873817^{*}$ \\
\hline LGFHDS & 1 & $4.134574^{*}$ & $4.433009^{*}$ \\
\hline LIDD & 1 & $3.486674^{*}$ & $3.785109^{*}$ \\
\hline LSDDP & 1 & $3.854404^{*}$ & $4.152839^{*}$ \\
\hline LADDP & 1 & $5.304828^{*}$ & $5.603263^{*}$ \\
\hline LDDGS & 1 & $5.720704^{*}$ & $6.019139^{*}$ \\
\hline & \multicolumn{4}{|c|}{ Note: } \\
\hline$*$ & \multicolumn{4}{|c|}{ Indicates lag order selected by the criterion } \\
\hline AIC: & \multicolumn{4}{|c|}{ Schormation Criterion } \\
\hline SC: & \multicolumn{4}{|c|}{}
\end{tabular}

According to Tabel 2, optimum lag period for all models is 1 (lag=1) based on 2 accepted information criteria (AIC and SC).

Table 3. Results from bound tests

\begin{tabular}{ccccccccccccc}
\hline & & & \multicolumn{10}{c}{ Significance } \\
\cline { 4 - 11 } Dependant & AIC & F-statistic & \multicolumn{9}{c}{ I0 Bound } & \multicolumn{7}{c}{ I1 Bound } \\
variable & lags & & $10 \%$ & $5 \%$ & $2.5 \%$ & $1 \%$ & & & $2.5 \%$ & $1 \%$ & \\
\hline LSHEIBMT & 1 & 0.169691 & 4.04 & 4.94 & 5.77 & 6.84 & 4.78 & 5.73 & 6.68 & 7.84 & No Cointegration \\
LMSHEIT & 1 & 1.762728 & 4.04 & 4.94 & 5.77 & 6.84 & 4.78 & 5.73 & 6.68 & 7.84 & No Cointegration \\
LBSHEIT & 1 & 4.097428 & 4.04 & 4.94 & 5.77 & 6.84 & 4.78 & 5.73 & 6.68 & 7.84 & Cointegration \\
LGSHEIT & 1 & 5.695436 & 4.04 & 4.94 & 5.77 & 6.84 & 4.78 & 5.73 & 6.68 & 7.84 & Cointegration \\
LPHDS & 1 & 5.022410 & 4.04 & 4.94 & 5.77 & 6.84 & 4.78 & 5.73 & 6.68 & 7.84 & Cointegration \\
LAPHDS & 1 & 5.008170 & 4.04 & 4.94 & 5.77 & 6.84 & 4.78 & 5.73 & 6.68 & 7.84 & Cointegration \\
LGFHDS & 1 & 8.117594 & 4.04 & 4.94 & 5.77 & 6.84 & 4.78 & 5.73 & 6.68 & 7.84 & Cointegration \\
LIDD & 1 & 3.528603 & 4.04 & 4.94 & 5.77 & 6.84 & 4.78 & 5.73 & 6.68 & 7.84 & No Cointegration \\
LSDDP & 1 & 9.018878 & 4.04 & 4.94 & 5.77 & 6.84 & 4.78 & 5.73 & 6.68 & 7.84 & Cointegration \\
LADDP & 1 & 2.881023 & 4.04 & 4.94 & 5.77 & 6.84 & 4.78 & 5.73 & 6.68 & 7.84 & No Cointegration \\
LDDGS & 1 & 5.943413 & 4.04 & 4.94 & 5.77 & 6.84 & 4.78 & 5.73 & 6.68 & 7.84 & Cointegration \\
\hline
\end{tabular}

Table 3 - reveals the cointegration relations among variables. Thus, there are the cointegration relations among state budget allocation for education (DDGS) and BSHEIT, GSHEIT, PHDS, APHDS, GFHDS, SDDP, DDGS. In other words, there is a long-term relations. Thus, based on the Narayan (2005) table, F-statistics is above 5\% minimum indicator. However, there is no cointegration relation among state budget allocations for education and LSHEIBMT, MSHEIT, IDD, SDDP. 


\section{ENTREPRENEURSHIP AND SUSTAINABILITY ISSUES}

ISSN 2345-0282 (online) http://jssidoi.org/jesi/

2019 Volume 7 Number 2 (December)

http://doi.org/10.9770/jesi.2019.7.2(63)

\subsection{ARDL- Results for Long Run Model}

Table 4. Long Run Coefficients

\begin{tabular}{lccccc}
\hline & Variable & Coefficient & Std. Error & t-Statistic & Prob. \\
\hline LSHEIBMT & LBEES & $0,027 * 0,3 * 8^{* *}$ & 0,030 & 0,911 & 0,379 \\
LMSHEIT & $\mathrm{C}$ & 12,0874 & 7,681 & 0.0000 \\
& LBEES & 0,018 & 0,053 & 0,347 & 0,734 \\
LBSHEIT & $\mathrm{C}$ & $8,388^{* * *}$ & 1,233 & 6,806 & 0.0000 \\
& LBEES & $0,037^{* *}$ & 0,011 & 3,393 & 0,004 \\
LGSHEIT & $\mathrm{C}$ & $9,653^{* * *}$ & 0,198 & 48,839 & 0.0000 \\
& LBEES & 0,127 & 0,116 & 1,092 & 0,298 \\
LPHDS & $\mathrm{C}$ & $7,498^{*}$ & 2,737 & 2,739 & 0,019 \\
& LBEES & 0,052 & 0,026 & 1,976 & 0,076 \\
LAPHDS & $\mathrm{C}$ & $6,450^{* * *}$ & 0,487 & 13,240 & 0.0000 \\
& LBEES & $-0,003$ & 0,098 & $-0,033$ & 0,974 \\
LGFHDS & $\mathrm{C}$ & $5,804^{* *}$ & 1,798 & 3,228 & 0,005 \\
& LBEES & $0,035^{* *}$ & 0,012 & 2,804 & 0,017 \\
LIDD & $\mathrm{C}$ & $5,192^{* * *}$ & 0,234 & 22,235 & 0.0000 \\
& LBEES & $0,179^{* *}$ & 0,053 & 3,376 & 0,004 \\
LSDDP & $\mathrm{C}$ & 0,509 & 0,917 & 0,555 & 0,586 \\
& LBEES & $0,282^{* * *}$ & 0,045 & 6,259 & 0,000 \\
LADDP & $\mathrm{C}$ & 0,349 & 0,780 & 0,448 & 0,664 \\
& LBEES & $0,247^{*}$ & 0,114 & 2,174 & 0,043 \\
LDDGS & $\mathrm{C}$ & $-0,778$ & 2,039 & $-0,382$ & 0,707 \\
& LBEES & 0,136 & 0,065 & 2,091 & 0,051 \\
& $\mathrm{C}$ & 0,534 & 1,183 & 0,452 & 0,657 \\
\hline
\end{tabular}

Note: $* * *, * *$ and $*$ indicate rejection of the null hypotheses at the $1 \%, 5 \%$ and $10 \%$ significance levels respectively

In Table 4, most of constants (model 1-9) in long run coefficients for all models are statistically significant. However, constant coefficient are statistically significant only in 5 models (model 3 and 10 (90\%), model 7 and 8 (99\%), model 10 (99\%).

Table 5.

State budget allocation for science and education State budget allocation for science and education (BEES) within a year increases $1 \%$

State budget allocation for science and education (BEES) within a year increases $1 \%$

State budget allocation for science and education (BEES) within a year increases $1 \%$

State budget allocation for science and education (BEES) within a year increases $1 \%$

State budget allocation for science and education (BEES) within a year increases $1 \%$

State budget allocation for science and education (BEES) within a year increases $1 \%$

State budget allocation for science and education (BEES) within a year increases $1 \%$

State budget allocation for science and education (BEES) within a year increases $1 \%$

State budget allocation for science and education (BEES) within a year increases $1 \%$

State budget allocation for science and education
The main indicators of education and science SHEIBMT decreases by $0.027 \%$

MSHEIT decreases by $0.018 \%$

BSHEIT decreases by $0.037 \%$

GSHEIT decreases by $0.127 \%$

PHDS decreases by $0.052 \%$

APHDS decreases by $0.003 \%$

GFHDS decreases by $0.035 \%$

IDD decreases by $0.179 \%$

SDDP decreases by $0.282 \%$

ADDP decreases by $0.247 \%$ 


\section{ENTREPRENEURSHIP AND SUSTAINABILITY ISSUES}

ISSN 2345-0282 (online) http://jssidoi.org/jesi/

2019 Volume 7 Number 2 (December)

http://doi.org/10.9770/jesi.2019.7.2(63)

(BEES) within a year increases $1 \%$

State budget allocation for science and education

(BEES) within a year increases $1 \%$

DDGS decreases by $0.136 \%$

The outcomes were explianed in Table 4 and 5. Thus, in case, expenses allocated by state budget for education increases (BEES) 1\%, the number of students at the higher education institutions grows(SHEIBMT) $0.027 \%$, the number of master students at the higher education institutions surges up (MSHEIT) 0.018\%, the number of bachelor students at the higher education institutions rises (BSHEIT) $0.037 \%$, the number of graduated students at the higher education institutions rockets (GSHEIT) $0.127 \%$, the number of institutions for philosophy degree goes up (PHDS) $0.052 \%$, the admission to philosophy degree program increases (APHDS) $0.003 \%$, the number of philosophy degree graduate students surges up (GFHDS) $0.035 \%$, the number of institutions for doctorate degree rises (IDD) $0.179 \%$, the number of students on doctorate degree program rockets (SDDP) $0.282 \%$, the admission to doctorate degree program goes up (ADDP) $0.247 \%$, the number of graduated students on doctorate degree increases (DDGS) $0.136 \%$.

\subsection{ARDL model}

Table 6. Coefficients ARDL model

\begin{tabular}{|c|c|c|c|c|c|c|}
\hline \multirow[b]{3}{*}{ Variable } & \multicolumn{6}{|c|}{ Coefficient } \\
\hline & Model 1 & Model 2 & Model 3 & Model 4 & Model 5 & Model 6 \\
\hline & $\triangle$ LSHEIBMT & $\triangle$ LLMSHEIT & $\triangle$ ALBSHEIT & $\triangle$ ALGSHEIT & $\triangle$ LPHDS & $\triangle \mathrm{LAPHDS}$ \\
\hline ALSHEIBMT $_{(\mathrm{t}-1)}$ & 0.16 & & & & & \\
\hline LSHEIBMT $_{(\mathrm{t}-1)}$ & -0.07 & & & & & \\
\hline${ }_{\text {LLMSHEIT }}^{(t-1)}$ & & $-0.76^{*}$ & & & & \\
\hline LMSHEIT $_{(\mathrm{t}-1)}$ & & 0.16 & & & & \\
\hline SLBSHEIT $_{(t-1)}$ & & & $-0.45^{*}$ & & & \\
\hline LBSHEIT $_{(t-1)}$ & & & $0.59 *$ & & & \\
\hline $\operatorname{ALGSHEIT}_{(\mathrm{t}-1)}$ & & & & $-0.45^{* *}$ & & \\
\hline LGSHEIT $_{(\mathrm{t}-1)}$ & & & & 0.48 & & \\
\hline $\operatorname{ALPHDS}_{(\mathrm{t}-1)}$ & & & & & 0.36 & \\
\hline LPHDS $_{(t-1)}$ & & & & & 0.09 & \\
\hline $\operatorname{SLAPHDS}_{(\mathrm{t}-1)}$ & & & & & & $-0.48 * *$ \\
\hline LAPHDS $_{(t-1)}$ & & & & & & $0.96 * * *$ \\
\hline $\operatorname{LLBEES}_{(\mathrm{t}-1)}$ & -0.007 & $-0.11 *$ & -0.003 & $-0.02 * *$ & 0.01 & -0.09 \\
\hline LBEES $_{(\mathrm{t}-1)}$ & 0.001 & -0.02 & -0.02 & $-0.02 * *$ & -0.004 & -0.002 \\
\hline Constant & 0.83 & -0.86 & $-5.69 *$ & $-4.51 * *$ & -0.63 & $-5.42 * *$ \\
\hline
\end{tabular}

Note: $* * *, * *$ and $*$ indicate rejection of the null hypotheses at the $1 \%, 5 \%$ and $10 \%$ significance levels respectively

Table 7. Coefficients ARDL model

Coefficient

\begin{tabular}{|c|c|c|c|c|c|}
\hline Variable & Model 7 & Model 8 & Model 9 & Model 10 & Model 11 \\
\hline $\operatorname{ALGFHDS}_{(\mathrm{t}-1)}$ & -0.36 & & & & \\
\hline LGFHDS $_{(t-1)}$ & $0.76^{* *}$ & & & & \\
\hline$\Delta \operatorname{LIDD}_{(\mathrm{t}-1)}$ & & -0.33 & & & \\
\hline $\operatorname{LIDD}_{(t-1)}$ & & 0.18 & & & \\
\hline$\Delta \operatorname{LSDDP}_{(t-1)}$ & & & 0.20 & & \\
\hline $\operatorname{LSDDP}_{(\mathrm{t} t-1)}$ & & & 0.04 & & \\
\hline$\triangle \mathrm{LADDP}_{(\mathrm{t}-1)}$ & & & & -0.25 & \\
\hline
\end{tabular}


ENTREPRENEURSHIP AND SUSTAINABILITY ISSUES

ISSN 2345-0282 (online) http://jssidoi.org/jesi/

2019 Volume 7 Number 2 (December)

http://doi.org/10.9770/jesi.2019.7.2(63)

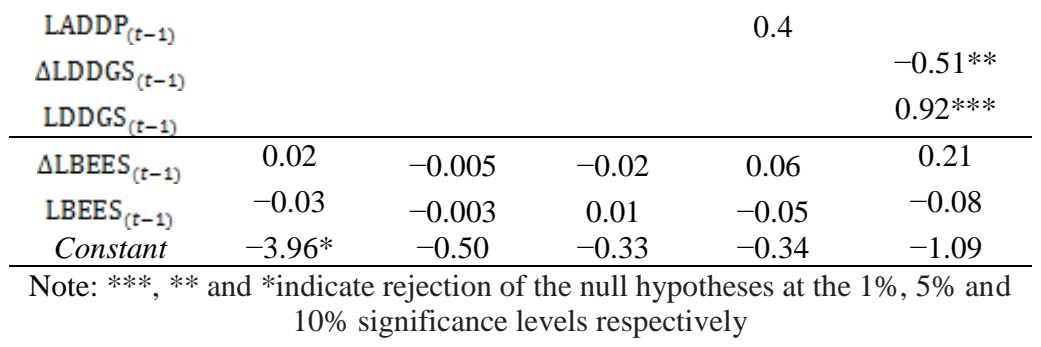

ARDL model coefficients are 90-95\% statistically significant only in models 2,3,4,5 and 11 (Table 6 and 7).

\subsection{ARDL- Results Error Correction (short run) Model}

Table 8. Error Correction (short run) Model Coefficients

\begin{tabular}{|c|c|c|c|c|c|c|}
\hline \multirow[b]{3}{*}{ Variable } & \multicolumn{6}{|c|}{ Coefficient } \\
\hline & Model 1 & Model 2 & Model 3 & Model 4 & Model 5 & Model 6 \\
\hline & $\triangle \mathrm{LSHEIBMT}$ & ALMSHEIT & $\triangle$ LBSHEIT & $\triangle$ LGSHEIT & $\triangle \mathrm{LPHDS}$ & $\triangle \mathrm{LAPHDS}$ \\
\hline$\Delta$ LSHEIBMT $_{(\mathbf{t}-1)}$ & 0.23 & & & & & \\
\hline ALMSHEIT $_{(t-1)}$ & & -0.36 & & & & \\
\hline $\operatorname{SLBSHEIT}_{(t-1)}$ & & & -0.07 & & & \\
\hline $\operatorname{SLGSHEIT}_{(\mathrm{t}-1)}$ & & & & -0.31 & & \\
\hline $\operatorname{ALPHDS}_{(\mathrm{t}-1)}$ & & & & & 0.71 & \\
\hline $\operatorname{SLAPHDS}_{(\mathrm{t}-1)}$ & & & & & & 0.31 \\
\hline $\operatorname{ALBEES}_{(\mathrm{t}-1)}$ & -0.003 & -0.08 & -0.03 & -0.03 & 0.03 & 0.10 \\
\hline ect $_{(t-1)}$ & $-0.17 *$ & -0.25 & $-0.52 *$ & -0.05 & $-0.45^{*}$ & $-0.95 * *$ \\
\hline Constant & $0.02 * *$ & $0.12 *$ & 0.03 & 0.05 & -0.02 & -0.05 \\
\hline
\end{tabular}

Table 9. Error Correction (short run) Model Coefficients

\begin{tabular}{|c|c|c|c|c|c|}
\hline Variable & $\begin{array}{l}\text { Model } 7 \\
\text { AlLGFHDS }\end{array}$ & $\begin{array}{l}\text { Model } 8 \\
\text { ALIDD }\end{array}$ & $\begin{array}{l}\text { Coefficien } \\
\text { Model } 9 \\
\text { ALSDDP }\end{array}$ & $\begin{array}{l}\text { Model } 10 \\
\text { ALADDP }\end{array}$ & $\begin{array}{l}\text { Model } 11 \\
\text { ALDDGS }\end{array}$ \\
\hline$\Delta$ LGFHDS $_{(t-1)}$ & $0.57 * *$ & & & & \\
\hline$\Delta \operatorname{LIDD}_{(\mathrm{t}-1)}$ & & -0.13 & & & \\
\hline$\Delta \operatorname{LSDDP}_{(\mathrm{t}-1)}$ & & & 0.39 & & \\
\hline$\Delta \mathrm{LADDP}_{(\mathrm{t}-1)}$ & & & & 0.10 & \\
\hline$\Delta \operatorname{LDDGS}_{(\mathrm{t}-1)}$ & & & & & 0.03 \\
\hline$\triangle \mathrm{LBEES}_{(\mathrm{t}-1)}$ & 0.02 & -0.03 & -0.02 & -0.03 & -0.02 \\
\hline$\theta c t_{(t-1)}$ & $-0.81 * * *$ & $-0.31 *$ & -0.17 & $-0.43 *$ & -0.83 \\
\hline Constant & -0.01 & 0.09 & 0.06 & 0.08 & 0.10 \\
\hline
\end{tabular}

The resuls of short-term and ECM model have been illustrated. The results are: there is a negative relation among expenses allocated by state budget for education (BEES) the number of students at the higher education institutions (SHEIBMT) (model 1), the number of master students at the higher education institutions (MSHEIT) (model 2), the number of bachelor students at the higher education institutions (BSHEIT) (model 3), the number of graduated students at the higher education institutions (GSHEIT) (model 4), the number of institutions for doctorate degree (IDD) (model 8), the number of students on doctorate degree program (SDDP) (Model 9), the 


\section{ENTREPRENEURSHIP AND SUSTAINABILITY ISSUES}

ISSN 2345-0282 (online) http://jssidoi.org/jesi/ 2019 Volume 7 Number 2 (December)

http://doi.org/10.9770/jesi.2019.7.2(63)

admission to doctorate degree program (ADDP) (model 10) and the number of doctorate degree graduate students (DDGS) (model 11). However, there is a positive relation among budget expenses (education and science) (BEES), the number of Phd students (PHDS) (model 5), the number of graduated PhD. students (APHDS) (model 6) and the number of Phd graduate students (GFHDS) (model 7) (Table 8 and 9).

On the other hand, etc. coefficient is negative in all cases. According to models, the inclination towards the balance in a long-term is 17\% (model 1), 25\% (model 2), 52\% (model 3), 5\% (model4), 45\% (model 5), 95\% (model 6), 81\% (model 7), 31\% (model 8), 17\% (model 9), 43\% (model 10). 83\% (model 11). In 2nd, 4th, 9th and 11th models, although ECM coefficient factors are not important, according to Pesaran and others (2001) they pave the way for having the cointegration relations because of negativity.

The weak and negative relations among the models prove that the main indicators of education and science don't depend on state budget allocations. There is a need to increase state budget allocations for science and education.

Table 10. Wald Test:

\begin{tabular}{ccccccccccc} 
& \multicolumn{2}{c}{ Model 1 } & \multicolumn{2}{c}{ Model 2 } & \multicolumn{2}{c}{ Model 3 } & \multicolumn{2}{c}{ Model 4 } & Model 5 \\
\hline & Value & Prob. & Value & Prob. & Value & Prob. & Value & Prob. & Value & Prob. \\
\cline { 2 - 10 } F-statistic & $4.01 *$ & 0.03 & 2.43 & 0.11 & $3.87 *$ & 0.05 & 0.68 & 0.51 & $4.99^{*}$ & 0.02 \\
Chi-square & $8.02 *$ & 0.01 & 4.86 & 0.0877 & $7.75^{*}$ & 0.02 & 1.37 & 0.50 & $9.99 * *$ & 0.01 \\
\hline \multicolumn{2}{c}{ Note: $* * *$} & $* *$ and $*$ indicate rejection of the null hypotheses at the $1 \%, 5 \%$ and $10 \%$ significance levels respectively
\end{tabular}

Table 11. Wald Test:

\begin{tabular}{ccccccccccccc} 
& \multicolumn{2}{c}{ Model 6 } & \multicolumn{2}{c}{ Model 7 } & \multicolumn{2}{c}{ Model 8 } & \multicolumn{2}{c}{ Model 9 } & \multicolumn{2}{c}{ Model 10 } & Model 11 \\
\hline & Value & Prob. & Value & Prob. & Value & Prob. & Value & Prob. & Value & Prob. & Value & Prob. \\
\cline { 2 - 11 } & $5.29^{*}$ & 0.01 & $7.19^{* *}$ & 0.01 & 2.00 & 0.17 & 1.66 & 0.22 & 2.87 & 0.08 & $3.63^{*}$ & 0.05 \\
F-statistic & $10.59^{* *}$ & 0.01 & $14.39^{* * *}$ & 0.001 & 401 & 0.13 & 3.33 & 0.18 & $5.75^{*}$ & 0.05 & $7.27^{*}$ & 0.02 \\
\hline \multicolumn{3}{c}{ Note: } & $* * *, * *$ and $*$ indicate rejection of the null hypotheses at the $1 \%, 5 \%$ and $10 \%$ significance levels respectively &
\end{tabular}

Wald Test results reveals that 1,3,5,6,7,10, and 11 models are $95 \%$ while model 7-I is $99 \%$ statistically significant (Table 10 and 11). So, "null" hypothesis is rejected and alternative hypothesis is accepted: there is cointegration relations among variables.

\subsection{Diagnostic Test}

Table 12. Diagnostic Test Results

\begin{tabular}{|c|c|c|c|c|c|c|c|c|}
\hline \multicolumn{6}{|c|}{ LM -Version } & \multicolumn{3}{|c|}{ F-Version } \\
\hline & & RESET & JB & H.ARCH $\chi^{2}$ & B-GSC LM $\chi^{2}$ & H.ARCH $\chi 2$ & B-GSC LM $\chi^{2}$ & RESET Test \\
\hline \multirow[t]{2}{*}{ LSHEIBMT } & Statistic & 1.97 & 1,050 & 0,521 & 3,278 & $\mathrm{~F}(1,16) 0.477$ & $\mathrm{~F}(2,11) 1.149$ & $\mathrm{~F}(1,12) 3,884$ \\
\hline & Sig & 0.072 & 0,592 & 0,471 & 0,194 & 0.499 & 0.352 & 0,072 \\
\hline \multirow[t]{2}{*}{ LMSHEIT } & Statistic & 1.162 & 5,298 & 0,533 & 3,088 & $\mathrm{~F}(1,17) 0.392$ & $\mathrm{~F}(2,13) 1.187$ & $F(1,14) 3,088$ \\
\hline & Sig & 0.265 & 0,071 & 0,465 & 0,214 & 0.492 & 0.336 & 0,214 \\
\hline \multirow[t]{2}{*}{ LBSHEIT } & Statistic & 0,776 & 23,958 & 0,006 & 0,255 & $\mathrm{~F}(1,16) 0.635$ & $\mathrm{~F}(2,13) 1.239$ & 4,874 \\
\hline & Sig & 0,975 & 0,000 & 0,940 & 0,614 & 0.351 & 0.336 & 0,042 \\
\hline \multirow[t]{2}{*}{ LGSHEIT } & Statistic & 0.182 & 1,471 & 0,255 & 4,829 & $\mathrm{~F}(1,17) 0.875$ & $\mathrm{~F}(2,13) 1.239$ & $\mathrm{~F}(1,10) 0,033$ \\
\hline & Sig & 0.857 & 0,479 & 0,614 & 0,089 & 0.307 & 0.336 & 0,859 \\
\hline \multirow[t]{2}{*}{ LPHDS } & Statistic & 0.583 & 1,418 & 0,035 & 6,157 & $\mathrm{~F}(1,15) 0.031$ & $\mathrm{~F}(2,8) 2.077$ & $F(1,9) 0,341$ \\
\hline & Sig & 0.571 & 0,492 & 0,851 & 0,046 & 0.862 & 0.187 & 0,574 \\
\hline \multirow[t]{2}{*}{ LAPHDS } & Statistic & 5.320 & 33,390 & 3,684 & 1,886 & $\mathrm{~F}(1,18) 4.065$ & $\mathrm{~F}(2,16) 0.789$ & $\mathrm{~F}(1,17) 28,323$ \\
\hline & Sig & 0.0001 & 0,000 & 0,055 & 0,390 & 0.059 & 0.471 & 0,000 \\
\hline \multirow[t]{2}{*}{ LGFHDS } & Statistic & 1.405 & 0,266 & 1,692 & 5,197 & $\mathrm{~F}(1,15) 1.657$ & $\mathrm{~F}(2,9) 1.825$ & $\mathrm{~F}(1,10) 1,976$ \\
\hline & Sig & 0.190 & 0,876 & 0,193 & 0,074 & 0.217 & 0.215 & 0,190 \\
\hline \multirow[t]{2}{*}{ LIDD } & Statistic & 0.777 & 14,574 & 1,468 & 2,832 & $\mathrm{~F}(1,18) 1.425$ & $\mathrm{~F}(2,15) 1.169$ & $\mathrm{~F}(1,16) 0,604$ \\
\hline & Sig & 0.448 & 0,001 & 0,226 & 0,243 & 0.248 & 0.337 & 0,448 \\
\hline LSDDP & Statistic & 0.661 & 0,337 & 2,386 & 13,319 & $\mathrm{~F}(1,15) 2.449$ & $\mathrm{~F}(2,8) 11.380$ & $F(1,9) 0,436$ \\
\hline
\end{tabular}




\section{ENTREPRENEURSHIP AND SUSTAINABILITY ISSUES}

ISSN 2345-0282 (online) http://jssidoi.org/jesi/

2019 Volume 7 Number 2 (December)

http://doi.org/10.9770/jesi.2019.7.2(63)

\begin{tabular}{|c|c|c|c|c|c|c|c|c|}
\hline & Sig & 0.525 & 0,845 & 0,122 & 0,001 & 0.138 & 0.0046 & 0,525 \\
\hline LADDP & Statistic & 1.377 & 22,044 & 0,671 & 2,507 & $\mathrm{~F}(1,18) 0.625$ & $\mathrm{~F}(2,16) 1.083$ & $\mathrm{~F}(1,17) 1,903$ \\
\hline & Sig & 0.187 & 0,000 & 0,412 & 0,286 & 0.439 & 0.361 & 1,903 \\
\hline LDDGS & Statistic & 0.287 & 1,111 & 0,509 & 0,717 & $\mathrm{~F}(1,18) 0.469$ & $\mathrm{~F}(2,160.292$ & $\mathrm{F}(1,17) 0,082$ \\
\hline & Sig & 0.777 & 0,574 & 0,476 & 0,699 & 0.501 & 0.757 & 0,778 \\
\hline
\end{tabular}

B-GSC LM $\chi 2$ - Breusch-Godfrey Serial Correlation LM Test: $\chi 2$; RESET- Ramsey RESET Test; JB- Normality Test (Jarque-Bera); H.ARCH $\chi^{2}-$ Heteroskedasticity Test: ARCH $\chi^{2}$

Some models for ARDL models (model 2,3,4,6 and model 11) are 5\% 1\% and $0.1 \%$ significant.

Regression equations are adequate. It also passes all the diagnostic tests against serial correlation (Durbin Watson test and Breusch-Godfrey test), heteroscedasticity (White Heteroskedasticity Test), and normality of errors (Jarque-Bera test). The Ramsey RESET test also suggests that the model is well specified. All the results of these tests are shown in Table 12. The stability of the long-run coefficient is tested by the short-run dynamics. Once the ECM model given by equations (Table 8 and 9) has been estimated, the cumulative sum of recursive residuals (CUSUM) and the CUSUM of square (CUSUMSQ) tests are applied to assess the parameter stability (Pesaran \& Pesaran, 1997). A.Figure1 plot the results for CUSUM and CUSUMSQ tests. The results indicate the absence of any instability of the coefficients because the plot of the CUSUM and CUSUMSQ statistic fall inside the critical bands of the $5 \%$ confidence interval of parameter stability.

\section{Discussion}

As a result of used test outcomes and models, we can note the followings: According to Single Root Test results, only small part of used variable are $\mathrm{I}(0)$, however, most of them are $\mathrm{I}(1)$. We can mention this as a cointegration relations among variables. There is a weak cointegration relation among variables. There is slightly weak relations among the significant degrees of ARDL model coefficients and ARDL - Results Error Correction (short run) model coefficients. Obviously, all requirements for models are satisfied. So, long run coefficeint which was included to the model as a constant variable is negative in some models and statististically significant in others. Besides, ECT diagnostic test in all models provided a positive outcome. In other words, there is no correlation and heteroscedasticity problem in any of these models. Standard regression error is small. ECT has been distributed equally. There is no specification problem in models. Because, the rejection of zero hypothesis is high.

\section{Conclusions}

The significance of science and education is increasing in the development of the world countries in modern period. The policy referred to science and education was directed to the development and formation of the human capital. The financing of education and science is considered one of the priorities of social policy in the countries. In the recent century, the fast development and the improvement of the democratic management principles of the world economy indicates that the financing and formation of the education is very important process in all the governments.

In the earlier days of independence, Azerbaijan got dividends having exporting oil into the world market and this process helped to ignore the hard days in the country effective to 2003. The fantastic increase of oil prices of 2005 in the world markets caused to flow a lot amount of money into Azerbaijan economy. Although the biggest part of allocations was invested on infrastructure, some other social sectors were also benefited from it.

The financing of education and science is divided into three parts for its sources. These are classified for state, private, international and mixed. State expenditures are priority that's why state sector is being financed a lot. 


\section{ENTREPRENEURSHIP AND SUSTAINABILITY ISSUES}

ISSN 2345-0282 (online) http://jssidoi.org/jesi/

2019 Volume 7 Number 2 (December)

http://doi.org/10.9770/jesi.2019.7.2(63)

Thus, citizens are benefited and get free education. Nonetheless, the biggest part of the expenditures are spent on infrastructure, that's why salary and education quality is still lacking to meet modern standards.

Recently, the significant part of the expenditure has been directed to infrastructure. So, the expenditures has been increased 5 times in the last 13 years, however investment on education has grown up 60 times. Educators' salary has been surged up 5 times. By the way, there is a tendency that the volume of the educator's salary is less than other sectors. This case may cause the poor quality of education.

Obviously, there is a huge demand to meet European standards of education quality and conduct comprehensive actions. For this purpose, it is very important to strengthen management style of education and increase teacher's reputation in the society.

With a view to solve the mentioned problems, a comprehensive action plan must be designed to create a competitive education system and contemporary infrastructure.

The current situation related to the financing of science and education in Azerbaijan was defined as the main direction. The implemented research is as the following:

- If the state expenditures for education and science were to increase, relative reduction would be observed in other fields;

- It would be better find alternative ways in the finance of education and science in order to prepare specialists who meet the world standards and play an important role in sustainable development;

- It must be seriously taken to have a weak relationship between the expenditures of education and science and the main indicators of science.

- It is important to make the state budget increase in order to obtain optimum dependency between the state expenditures on education and science and the main indicators of them;

- The expenditures on education and science must be concrete and significant;

- The financing of higher education, especially master and doctorate degree education must be priority.

There is a problem to provide the balance between the quality of education and science and the expenditure of them. Because the research shows that there is no any significant improvement although a lot of investment was allocated. That's why, establishing a new and diversified financing mechanism is a must.

\section{Limitations and future research orientations}

During research, it was revealed that although the bduget allocation for education was high in the last 10-15 years, this tendency was not the same as economic growth and as a result of it, education expenses decreased in GDP. On the other hand, the special weight of the expenses allocated for education and science declined in general budget expenditures. However, expenditures related to science and education surged up in spite of the reductions. Investment for science and education rockets as well. But having inaccurate statistical data and its absence for a long term made some difficulties to choose some econometric models, to evaluate variables, to conduct tests and etc.

- We can mention some of the future research directions as the following:

- Private and international financing of science and education

- Economic analysis of salary expenditures in state allocation for science and education

- Investment and infrastructure expenditure analysis in state allocations for education and science. 
ENTREPRENEURSHIP AND SUSTAINABILITY ISSUES

ISSN 2345-0282 (online) http://jssidoi.org/jesi/

2019 Volume 7 Number 2 (December)

http://doi.org/10.9770/jesi.2019.7.2(63)

\section{Appendix}

A. Table 1. ADF Unit Root Test.

\begin{tabular}{|c|c|c|c|c|c|c|c|}
\hline & & ADF-Stat & $\begin{array}{l}\text { İntegrir } \\
\dot{\mathrm{I}}(0,1,2)\end{array}$ & $\begin{array}{l}\mathrm{P}-\mathrm{P} \text { test } \\
\text { statistic }\end{array}$ & $\begin{array}{l}\text { İntegrir } \\
\dot{\mathrm{I}}(0,1,2)\end{array}$ & $\begin{array}{c}\text { KPSS test } \\
\text { statistic }\end{array}$ & $\begin{array}{l}\text { İntegrir } \\
\dot{I}(0,1,2) \\
\end{array}$ \\
\hline & & & At L & el Form & & & \\
\hline & LSHEIBMT & -0.19 & $\mathrm{I}(1)$ & -0.50 & $\mathrm{I}(1)$ & $0.66 * *$ & $\mathrm{I}(0)$ \\
\hline & LMSHEIT & -1.47 & $\mathrm{I}(1)$ & -1.42 & $\mathrm{I}(1)$ & $0.55 * *$ & $\mathrm{I}(0)$ \\
\hline & LBSHEIT & -1.41 & $\mathrm{I}(1)$ & -1.12 & $\mathrm{I}(1)$ & $0.62 * *$ & $\mathrm{I}(0)$ \\
\hline & LGSHEIT & -1.90 & $\mathrm{I}(1)$ & -1.99 & $\mathrm{I}(1)$ & $0.61 * *$ & $\mathrm{I}(0)$ \\
\hline & LPHDS & -2.57 & $\mathrm{I}(1)$ & -1.47 & $\mathrm{I}(1)$ & $0.35^{*}$ & $\mathrm{I}(0)$ \\
\hline & LAPHDS & $-3.25 * *$ & $\mathrm{I}(0)$ & $-3.12 * *$ & $\mathrm{I}(0)$ & 0.09 & \\
\hline & LGFHDS & $-3.37 * *$ & $\mathrm{I}(0)$ & -2.33 & $\mathrm{I}(1)$ & 0.20 & \\
\hline & LIDD & -0.39 & $\mathrm{I}(1)$ & -0.01 & $\mathrm{I}(1)$ & $0.55 * *$ & $\mathrm{I}(0)$ \\
\hline & LSDDP & -0.10 & $\mathrm{I}(1)$ & -0.10 & $\mathrm{I}(1)$ & $0.52 * *$ & $\mathrm{I}(0)$ \\
\hline & LADDP & -1.13 & $\mathrm{I}(1)$ & -0.97 & $\mathrm{I}(1)$ & $0.51 * *$ & $\mathrm{I}(0)$ \\
\hline & LDDGS & -2.55 & $\mathrm{I}(1)$ & -2.55 & $\mathrm{I}(1)$ & $0.52 * *$ & $\mathrm{I}(0)$ \\
\hline & LBEES & -0.95 & $\mathrm{I}(1)$ & -0.92 & $\mathrm{I}(1)$ & $0.58 * *$ & $\mathrm{I}(0)$ \\
\hline & & & At First & lifferencing & & & \\
\hline & D(LSHEIBMT) & $-6.53 * * *$ & $\mathrm{I}(0)$ & $-4.18 * * *$ & $\mathrm{I}(0)$ & 0.30 & \\
\hline & D(LMSHEIT) & $-4.16^{* * *}$ & $\mathrm{I}(0)$ & $-4.16^{* * *}$ & $\mathrm{I}(0)$ & 0.09 & \\
\hline & D(LBSHEIT) & $-6.17 * * *$ & $\mathrm{I}(0)$ & $-13.09 * * *$ & $\mathrm{I}(0)$ & $0.50 * *$ & $\mathrm{I}(0)$ \\
\hline & D(LGSHEIT) & $-6.84 * * *$ & $\mathrm{I}(0)$ & $-7.77 * * *$ & $\mathrm{I}(0)$ & $0.42 *$ & $\mathrm{I}(0)$ \\
\hline & D(LPHDS) & $-3.45 * *$ & $\mathrm{I}(0)$ & $-2.71 *$ & $\mathrm{I}(0)$ & 0.09 & \\
\hline & D(LAPHDS) & $-5.02 * * *$ & $\mathrm{I}(0)$ & $-10.43 * * *$ & $\mathrm{I}(0)$ & 0.06 & \\
\hline & $\mathrm{D}$ (LGFHDS) & $-4.16^{* * *}$ & $\mathrm{I}(0)$ & $-4.06 * * *$ & $\mathrm{I}(0)$ & 0.12 & \\
\hline & $\mathrm{D}$ (LIDD) & $-5.55 * * *$ & $\mathrm{I}(0)$ & $-5.77 * * *$ & $\mathrm{I}(0)$ & 0.25 & \\
\hline & $\mathrm{D}$ (LSDDP) & $-3.10 * *$ & $\mathrm{I}(0)$ & $-3.10 * *$ & $\mathrm{I}(0)$ & 0.20 & \\
\hline & D(LADDP) & $-4.65 * * *$ & $\mathrm{I}(0)$ & $-5.32 * * *$ & $\mathrm{I}(0)$ & 0.25 & \\
\hline & $\mathrm{D}$ (LDDGS) & $-6.35 * * *$ & $\mathrm{I}(0)$ & $-7.88 * * *$ & $\mathrm{I}(0)$ & 0.25 & \\
\hline & D(LBEES) & $-4.17 * * *$ & $\mathrm{I}(0)$ & $-4.17 * * *$ & $\mathrm{I}(0)$ & 0.11 & \\
\hline & & & At L & el Form & & & \\
\hline & LSHEIBMT & 4.87 & $\mathrm{I}(1)$ & -2.12 & $\mathrm{I}(1)$ & 0.09 & \\
\hline & LMSHEIT & -2.25 & $\mathrm{I}(1)$ & -1.60 & $\mathrm{I}(1)$ & 0.09 & \\
\hline & LBSHEIT & $-3.61 *$ & $\mathrm{I}(0)$ & $-3.57 *$ & $\mathrm{I}(0)$ & 0.15 & \\
\hline & LGSHEIT & $-3.34 *$ & $\mathrm{I}(0)$ & $-3.37 *$ & $\mathrm{I}(0)$ & 0.17 & \\
\hline & LPHDS & $-4.20 * *$ & $\mathrm{I}(0)$ & -2.18 & $\mathrm{I}(1)$ & 0.08 & \\
\hline & LAPHDS & -3.19 & $\mathrm{I}(1)$ & -3.09 & $\mathrm{I}(1)$ & 0.06 & \\
\hline & LGFHDS & $-3.53^{*}$ & $\mathrm{I}(0)$ & -2.48 & $\mathrm{I}(1)$ & 0.06 & \\
\hline & LIDD & -2.34 & $\mathrm{I}(1)$ & -2.26 & $\mathrm{I}(1)$ & 0.15 & \\
\hline & LSDDP & -2.48 & $\mathrm{I}(1)$ & -1.64 & $\mathrm{I}(1)$ & 0.15 & \\
\hline With & LADDP & -2.56 & $\mathrm{I}(1)$ & -2.41 & $\mathrm{I}(1)$ & 0.12 & \\
\hline Intercept & LDDGS & $-3.42 *$ & $\mathrm{I}(0)$ & $-3.42 *$ & $\mathrm{I}(0)$ & 0.10 & \\
\hline \& Trend & LBEES & -1.59 & $\mathrm{I}(1)$ & -1.70 & $\mathrm{I}(1)$ & 0.09 & \\
\hline & & & At First & lifferencing & & & \\
\hline & D(LSHEIBMT) & $-6.21 * * *$ & $\mathrm{I}(0)$ & $-4.17 * *$ & $\mathrm{I}(0)$ & $0.38 * * *$ & $\mathrm{I}(0)$ \\
\hline & D(LMSHEIT) & $-4.05 * *$ & $\mathrm{I}(0)$ & $-4.02 * *$ & $\mathrm{I}(0)$ & 0.08 & \\
\hline & D(LBSHEIT) & $-3.80 * *$ & $\mathrm{I}(0)$ & $-15.38 * * *$ & $\mathrm{I}(0)$ & $0.50 * * *$ & $\mathrm{I}(0)$ \\
\hline & D(LGSHEIT) & $-6.60 * * *$ & $\mathrm{I}(0)$ & $-7.53 * * *$ & $\mathrm{I}(0)$ & $0.30 * * *$ & $\mathrm{I}(0)$ \\
\hline & $\mathrm{D}(\mathrm{D}(\mathrm{LPHDS}))$ & & & -2.70 & $\mathrm{I}(2)$ & & \\
\hline & D(LPHDS) & $-3.41 *$ & $\mathrm{I}(0)$ & $-3.76^{*}$ & $\mathrm{I}(0)$ & 0.07 & \\
\hline & D(LAPHDS) & $-4.88 * * *$ & $\mathrm{I}(0)$ & $-10.19 * * *$ & $\mathrm{I}(0)$ & $0.50 * * *$ & $\mathrm{I}(0)$ \\
\hline & D(LGFHDS) & $-4.16 * *$ & $\mathrm{I}(0)$ & $-4.02 * *$ & $\mathrm{I}(0)$ & $0.15 * *$ & $\mathrm{I}(0)$ \\
\hline & $\mathrm{D}(\mathrm{LIDD})$ & $-5.55 * * *$ & $\mathrm{I}(0)$ & $-6.30 * * *$ & $\mathrm{I}(0)$ & $0.18 * *$ & $\mathrm{I}(0)$ \\
\hline
\end{tabular}


ENTREPRENEURSHIP AND SUSTAINABILITY ISSUES

ISSN 2345-0282 (online) http://jssidoi.org/jesi/ 2019 Volume 7 Number 2 (December) http://doi.org/10.9770/jesi.2019.7.2(63)

\begin{tabular}{|c|c|c|c|c|c|c|c|}
\hline & $\mathrm{D}(\mathrm{LSDDP})$ & $-3.26^{*}$ & $\mathrm{I}(0)$ & $-3.26^{*}$ & $\mathrm{I}(0)$ & 0.09 & \\
\hline & $\mathrm{D}($ LADDP $)$ & $-4.57 * * *$ & $\mathrm{I}(0)$ & $-6.12 * * *$ & $\mathrm{I}(0)$ & $0.39 * * *$ & $\mathrm{I}(0)$ \\
\hline & D(LDDGS) & $-6.17 * * *$ & $\mathrm{I}(0)$ & $-8.54 * * *$ & $\mathrm{I}(0)$ & $0.25 * * *$ & $\mathrm{I}(0)$ \\
\hline & D(LBEES) & $-4.17 * * *$ & $\mathrm{I}(0)$ & $-4.08 * *$ & $\mathrm{I}(0)$ & 0.10 & \\
\hline \multirow{27}{*}{$\begin{array}{c}\text { No } \\
\text { Intercept } \\
\& \\
\text { No } \\
\text { Trend }\end{array}$} & \multicolumn{7}{|c|}{ At Level Form } \\
\hline & LSHEIBMT & 1.25 & $\mathrm{I}(1)$ & 10.05 & $\mathrm{I}(1)$ & & \\
\hline & LMSHEIT & 1.52 & $\mathrm{I}(1)$ & -2.31 & $\mathrm{I}(1)$ & & \\
\hline & LBSHEIT & 1.02 & $\mathrm{I}(1)$ & $4.17 * * *$ & $\mathrm{I}(0)$ & & \\
\hline & LGSHEIT & 1.38 & $\mathrm{I}(1)$ & 3.38 & $\mathrm{I}(1)$ & & \\
\hline & LPHDS & 0.59 & $\mathrm{I}(1)$ & 0.37 & $\mathrm{I}(1)$ & & \\
\hline & LAPHDS & 0.48 & $\mathrm{I}(1)$ & -0.18 & $\mathrm{I}(1)$ & & \\
\hline & LGFHDS & 0.20 & $\mathrm{I}(1)$ & 0.43 & $\mathrm{I}(1)$ & & \\
\hline & LIDD & 0.99 & $\mathrm{I}(1)$ & 1.41 & $\mathrm{I}(1)$ & & \\
\hline & LSDDP & 1.57 & $\mathrm{I}(1)$ & 1.36 & $\mathrm{I}(1)$ & & \\
\hline & LADDP & 0.30 & $\mathrm{I}(1)$ & 0.89 & $\mathrm{I}(1)$ & & \\
\hline & LDDGS & 0.42 & $\mathrm{I}(1)$ & 0.81 & $\mathrm{I}(1)$ & & \\
\hline & LBEES & 1.25 & $\mathrm{I}(1)$ & 1.25 & $\mathrm{I}(1)$ & & \\
\hline & \multicolumn{7}{|c|}{ At First differencing } \\
\hline & D(LSHEIBMT) & -0.77 & $\mathrm{I}(2)$ & $-2.32 * *$ & $\mathrm{I}(0)$ & & \\
\hline & D(D(LSHEIBMT) & $-6.15 * * *$ & $\mathrm{I}(0)$ & & & & \\
\hline & D(LMSHEIT) & $-3.80 * * *$ & $\mathrm{I}(0)$ & $-3.81 * * *$ & $\mathrm{I}(0)$ & & \\
\hline & D(LBSHEIT) & $-5.92 * * *$ & $\mathrm{I}(0)$ & $-6.10 * * *$ & $\mathrm{I}(0)$ & & \\
\hline & D(LGSHEIT) & $-6.43 * * *$ & $\mathrm{I}(0)$ & $-6.37 * * *$ & $\mathrm{I}(0)$ & & \\
\hline & D(LPHDS) & $-3.47 * * *$ & $\mathrm{I}(0)$ & $-2.75 * * *$ & $\mathrm{I}(0)$ & & \\
\hline & D(LAPHDS) & $-5.17 * * *$ & $\mathrm{I}(0)$ & $-10.71 * * *$ & $\mathrm{I}(0)$ & & \\
\hline & D(LGFHDS) & $-4.26 * * *$ & $\mathrm{I}(0)$ & $-4.12 * * *$ & $\mathrm{I}(0)$ & & \\
\hline & $\mathrm{D}$ (LIDD) & $-5.20 * * *$ & $\mathrm{I}(0)$ & $-5.20 * * *$ & $\mathrm{I}(0)$ & & \\
\hline & D(LSDDP) & $-2.96 * * *$ & $\mathrm{I}(0)$ & $-2.97 * * *$ & $\mathrm{I}(0)$ & & \\
\hline & $\mathrm{D}($ LADDP $)$ & $-4.67 * * *$ & $\mathrm{I}(0)$ & $-4.85 * * *$ & $\mathrm{I}(0)$ & & \\
\hline & D(LDDGS) & $-6.33 * * *$ & $\mathrm{I}(0)$ & $-7.02 * * *$ & $\mathrm{I}(0)$ & & \\
\hline & D(LBEES) & $-3.89 * * *$ & $\mathrm{I}(0)$ & $-3.88 * * *$ & $\mathrm{I}(0)$ & & \\
\hline \multicolumn{8}{|c|}{$\begin{array}{l}\text { Note: ADF denotes the Augmented Dickey-Fuller single root system respectively. The maximum lag } \\
\text { order is } 2 \text {. The optimum lag order is selected based on the Shwarz criterion automatically; PP } \\
\text { Phillips-Perron is single root system. The optimum lag order in PP test is selected based on the } \\
\text { Newey-West criterion automatically; KPSS denotes Kwiatkowski-Phillips-Schmidt-Shin } \\
\text { (Kwiatkowski et al., 1992) single root system. The optimum lag order in KPSS test is selected based } \\
\text { on the Newey-West criterion automatically; The critical values are taken from Kwiatkowski-Phillips- } \\
\text { Schmidt-Shin. } * * *, * * \text { and *indicate rejection of the null hypotheses at the } 1 \%, 5 \% \text { and } 10 \% \\
\text { significance levels respectively. The critical values are taken from MacKinnon (1996). Assessment } \\
\text { period: } 1996-2017 \text {. }\end{array}$} \\
\hline
\end{tabular}

A.Figure 1. Plot of Cumulative Sum of Recursive Residuals

\begin{tabular}{|l|l|l|l|l|}
\hline Model 1 & Model 3 \\
\hline Stability & Stability & Stability & Stability \\
\hline
\end{tabular}




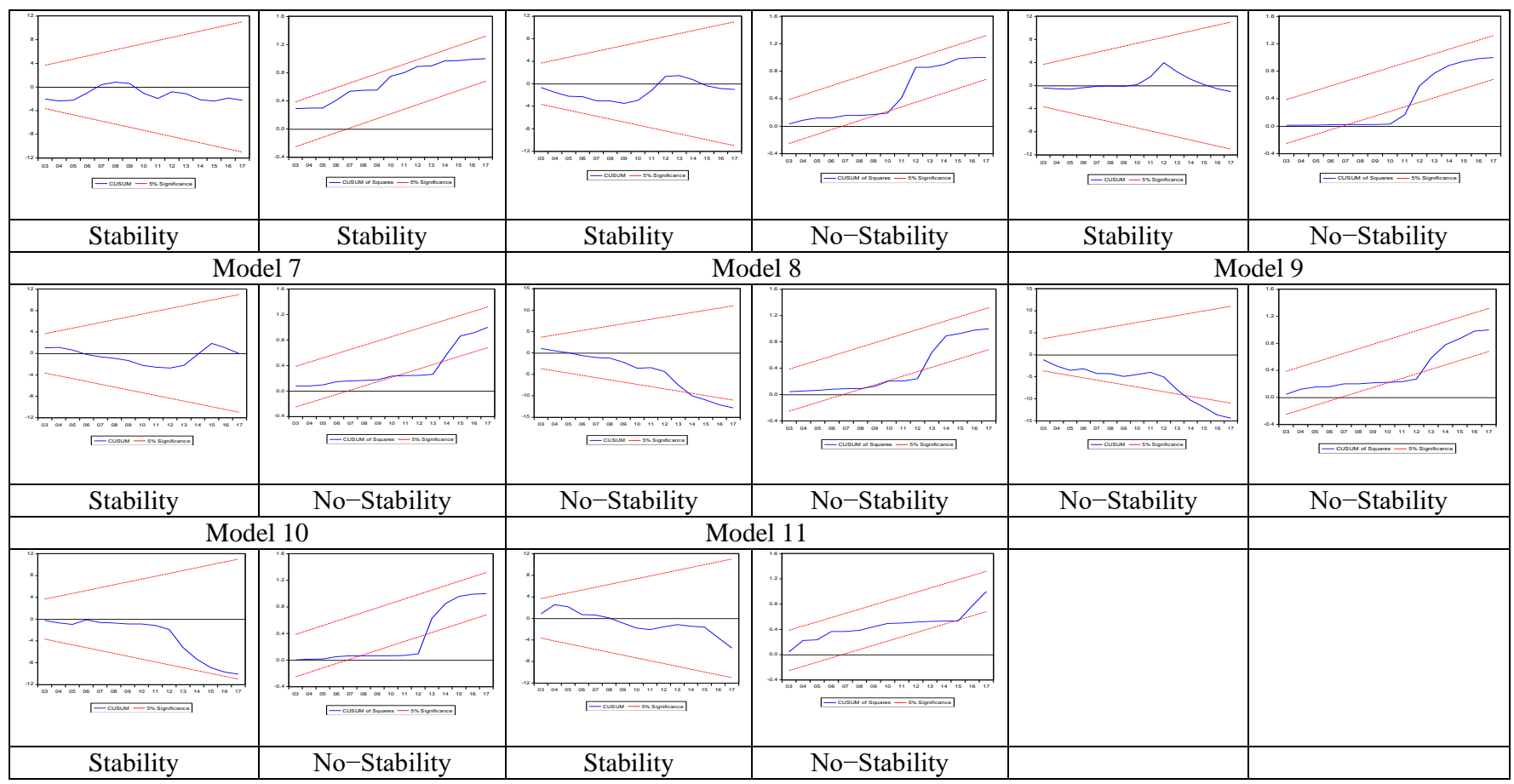

A. Figure2. Dynamic
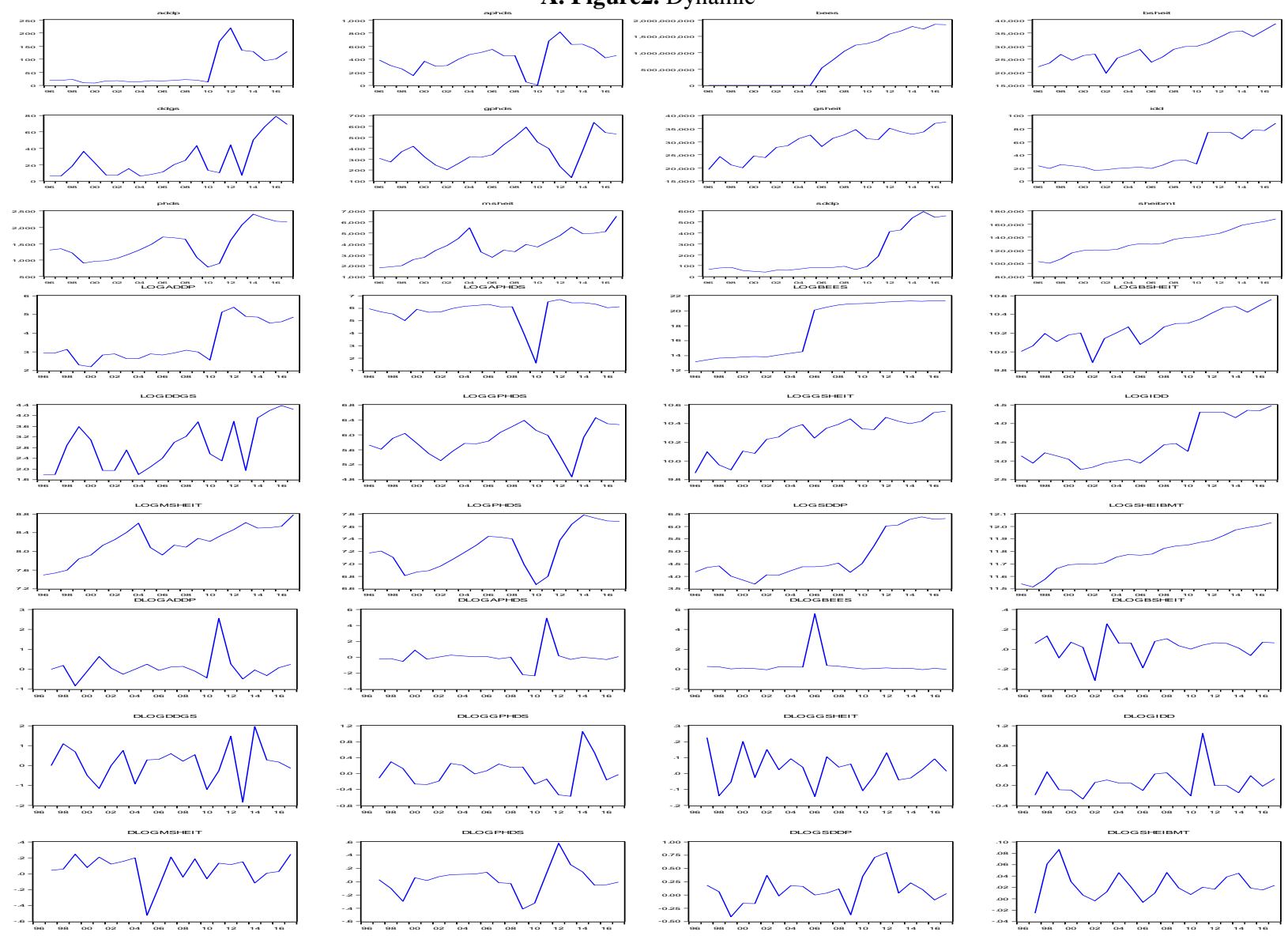
ENTREPRENEURSHIP AND SUSTAINABILITY ISSUES

ISSN 2345-0282 (online) http://jssidoi.org/jesi/

2019 Volume 7 Number 2 (December)

http://doi.org/10.9770/jesi.2019.7.2(63)

A. Table 4. ADF unit root test (At Level Form)

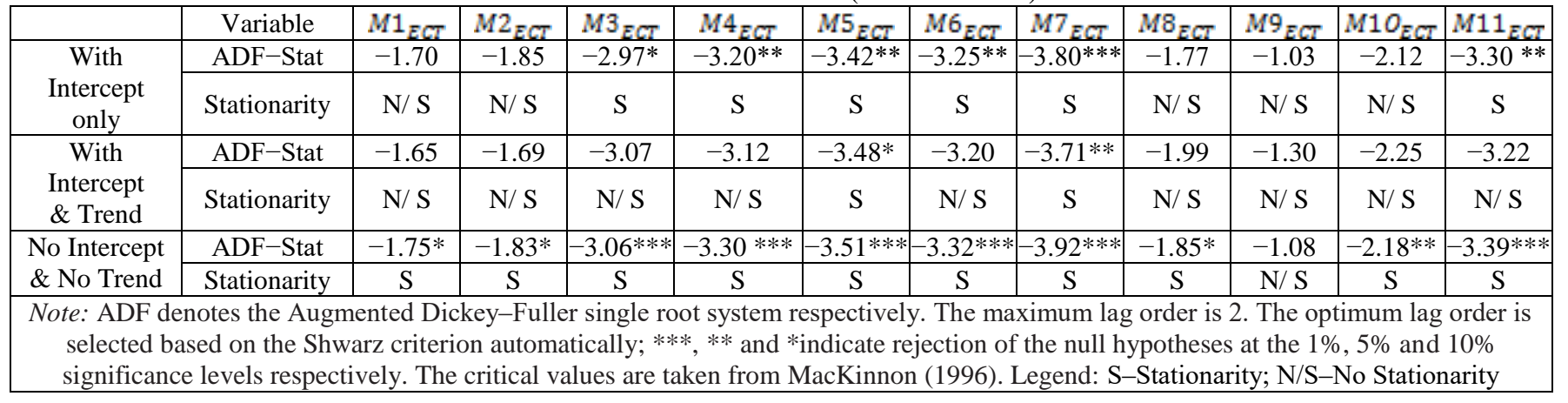

A.Table 5. Diagnostic Test Results

\begin{tabular}{|c|c|c|c|c|c|c|c|c|}
\hline \multicolumn{6}{|c|}{ LM -Version } & \multicolumn{3}{|c|}{ F -Version } \\
\hline & & RESET & JB & H.ARCH $\chi^{2}$ & B-GSC LM $\chi^{2}$ & H.ARCH $\chi 2$ & B-GSC LM $\chi^{2}$ & RESET Test \\
\hline \multirow[t]{2}{*}{ LSHEIBMT } & Statistic & 2.123 & 1.080 & 1.338 & 7.314 & $\mathrm{~F}(1,16) 0.477$ & $\mathrm{~F}(2,11) 1.149$ & $(1,14) 4.509$ \\
\hline & Sig & 0.052 & 0.582 & 0.247 & 0.025 & 0.499 & 0.352 & 0.052 \\
\hline \multirow[t]{2}{*}{ LMSHEIT } & Statistic & 2.990 & 1.119 & 2.731 & 0.029 & $\mathrm{~F}(1,17) 0.288$ & $\mathrm{~F}(2,13) 3.748$ & $(1,14) 8.942$ \\
\hline & Sig & 0.009 & 0.571 & 0.098 & 0.985 & 0.2721 & 0.051 & 0.009 \\
\hline \multirow[t]{2}{*}{ LBSHEIT } & Statistic & 0.557 & 10.275 & 0.146 & 2.028 & $\mathrm{~F}(1,17) 2.854$ & $\mathrm{~F}(2,13) 0.009$ & $(1,14) 0.311$ \\
\hline & Sig & 0.586 & 0.005 & 0.702 & 0.362 & 0.1094 & 0.9903 & 0.586 \\
\hline \multirow[t]{2}{*}{ LGSHEIT } & Statistic & 0.830 & 1.552 & 1.917 & 2.230 & $\mathrm{~F}(1,17) 0.131$ & $\mathrm{~F}(2,13) 0.733$ & $(1,14) 0.689$ \\
\hline & Sig & 0.420 & 0.460 & 0.166 & 0.327 & 0.7211 & 0.4991 & 0.420 \\
\hline \multirow[t]{2}{*}{ LPHDS } & Statistic & 0.017 & 2.108 & 0.008 & 0.416 & $\mathrm{~F}(1,17) 1.908$ & $\mathrm{~F}(2,13) 0.815$ & $(1,14) 0.000$ \\
\hline & Sig & 0.985 & 0.348 & 0.928 & 0.811 & 0.185 & 0.463 & 0.9859 \\
\hline \multirow[t]{2}{*}{ LAPHDS } & Statistic & 5.851 & 18.562 & 3.359 & 1.031 & $\mathrm{~F}(1,17) 0.007$ & $\mathrm{~F}(2,13) 0.138$ & $(1,14) 34.237$ \\
\hline & Sig & 0.000 & 0.000 & 0.066 & 0.597 & 0.933 & 0.872 & 0.000 \\
\hline \multirow[t]{2}{*}{ LGFHDS } & Statistic & 1.751 & 2.126 & 5.403 & 6.065 & $F(1,17) 3.651$ & $\mathrm{~F}(2,13) 0.353$ & $(1,14) 3.065$ \\
\hline & Sig & 0.102 & 0.345 & 0.020 & 0.048 & 0.073 & 0.708 & 0.101 \\
\hline \multirow[t]{2}{*}{ LIDD } & Statistic & 2.769 & 4.122 & 3.964 & 4.690 & $\mathrm{~F}(1,17) 0.756$ & $\mathrm{~F}(2,13) 2.829$ & $(1,14) 7.667$ \\
\hline & Sig & 0.015 & 0.127 & 0.047 & 0.095 & 0.018 & 0.095 & 0.015 \\
\hline \multirow[t]{2}{*}{ LSDDP } & Statistic & 0.634 & 3.022 & 0.202 & 1.770 & $\mathrm{~F}(1,17) 0.482$ & $\mathrm{~F}(2,13) 1.991$ & $(1,14) 0.402$ \\
\hline & Sig & 0.536 & 0.220 & 0.652 & 0.412 & 0.049 & 0.176 & 0.5361 \\
\hline \multirow[t]{2}{*}{ LADDP } & Statistic & 0.775 & 1.462 & 2.878 & 4.098 & $\mathrm{~F}(1,17) 0.183$ & $\mathrm{~F}(2,13) 0.631$ & $\mathrm{~F}(1,14) 0.601$ \\
\hline & Sig & 0.451 & 0.481 & 0.089 & 0.128 & 0.674 & 0.547 & 0.4510 \\
\hline \multirow[t]{2}{*}{ LDDGS } & Statistic & 2.237 & 3.022 & 0.014 & 1.292 & $\mathrm{~F}(1,17) 0.034$ & $\mathrm{~F}(2,13) 1.675$ & $\mathrm{~F}(1,14) 5.007$ \\
\hline & Sig & 0.042 & 0.220 & 0.905 & 0.523 & 0.0996 & 0.2252 & 0.0420 \\
\hline
\end{tabular}

\section{A. Abbreviations}

\begin{tabular}{cc}
\hline SHEIBMT & The number of students at the higher education institutions - total, person \\
MSHEIT & The number of master students at the higher education institutions (admission) - total, person \\
BSHEIT & The number of bachelor students at the higher education institutions (admission) - total, person \\
GSHEIT & The number of graduated students at the higher education institutions - total, person \\
PhDS & The number of Phd students - person \\
APhDS & Admission to Phd programs - person \\
GPhDS & The number of graduated Phd students, person \\
IDD & The number of institutions for doctorate degree \\
SDDP & The number of students on doctorate degree program - person \\
ADDP & The admission to doctorate degree program - person \\
DDGS & The number of doctorate degree graduate students - person \\
BEES & Budget expenses (education and science) - mln.manat
\end{tabular}




\section{ENTREPRENEURSHIP AND SUSTAINABILITY ISSUES}

ISSN 2345-0282 (online) http://jssidoi.org/jesi/

2019 Volume 7 Number 2 (December)

http://doi.org/10.9770/jesi.2019.7.2(63)

\section{References}

Adam, Jaffe 1989. The Real Effects of Academic Research. American Economic Review, 79, 957-770. https://www.researchgate.net/publication/4729106 The Real Effects of Academic Research

Adel, Ifa \& Guetat, Imène. 2018. Does public expenditure on education promote Tunisian and Moroccan GDP per capita? ARDL approach. The Journal of Finance and Data Science. 4. https://doi.org/10.1016/j.jfds.2018.02.005

Nadirov, Orkhan \& Aliyev, Khatai. 2016. How Fiscal Policy Affects Non-Oil Economic Performance in Azerbaijan?. Academic Journal of Economic Studies, 2, 11-29. https://doi.org/10.2139/ssrn.2884267.

Ahmed, A. M., Liu, Z. 2019. Assessment of Sustainable Development of the Performance of Higher Education Credentials in the Transitive Labor Market. Sustainability, 11, 2628; https://doi.org/10.3390/su11092628

Alonso-Borrego, César \& Romero-Medina, Antonio \& Sánchez-Mangas, Rocío. 2017. The impact of public research contracts on scientific productivity. Applied Economics, 49, 417-432. https://doi.org/10.1080/00036846.2016.1200181.

Albrecht, Carl. 2014. A Bibliometric Analysis of Research Publications Funded Partially by the Cancer Association of South Africa (CANSA) during a 10-year Period (1994-2003). South African Family Practice, 51, 73-76. https://doi.org/10.1080/20786204.2009.10873812.

Arbo, Peter \& Benneworth, Paul. 2007. Understanding the Regional Contribution of Higher Education Institutions: A Literature Review. OECD, Directorate for Education, OECD Education Working Papers. https://doi.org/10.1787/161208155312.

Asteriou, D., Hall, S.G. 2007. Applied Econometrics; Revised Edition; Red Globe Press: London, UK, 552. http://bookre.org/reader?file $=1276258$

Bárbara, C., Carla, Míguez-Álvarez, María, E.A., Miguel, C.; Luis, J. M. 2017. The Sustainable Development Goals: An Experience on Higher Education Sustainability, 9, 1353; https://doi.org/10.3390/su9081353

Bewley, R.A. 1979. The Direct Estimation of the Equilibrium Response in a Linear Dynamic Model. Economics Letters, 3, 357-361. https://doi.org/10.1016/0165-1765(79)90011-9.

Burmeister, M., Rauch, F. \& Eilks, I. 2012. Education for Sustainable Development (ESD) and chemistry education. Chemistry Education Research and Practice, 13, 59-68. https://doi.org/110.1039/C1RP90060A.

Butt, Safdar \& Hassan, Arshad. 2008. Role of Trade, External Debt, Labor Force and Education in Economic Growth: Empirical Evidence from Pakistan by Using ARDL Approach. European Journal of Scientific Research, 20(4). https://ssrn.com/abstract=1732512

Bradley, J. D. Chemistry education for development. Chemical Education International, 2005, 7, retrieved from the World Wide Web, July 01, 2011, http://old.iupac.org/publications/cei/vol6/index.html.

Chalkley, Brian. 2006. Education for Sustainable Development: Continuation. Journal of Geography in Higher Education, 30, 235-236. https://doi.org/10.1080/03098260600717307.

Cortese, Anthony. 2003. The Role of Higher Education in Creating a Sustainable Future. Planning for Higher Education 31, 15-25. http://citeseerx.ist.psu.edu/viewdoc/download?doi=10.1.1.739.3611\&rep=rep1\&type=pdf

Dahal, Madhav. 2015. Does higher education affect total factor productivity in Nepal? An exploration through the lens of ARDL bounds test. Economic Journal of Development Issues, 15. https://doi.org/10.3126/ejdi.v15i1-2.11869.

Enders, W. 2010. Applied econometrics time series, University of Alabama, Wiley Series in Probability and Statistics, 4th edition http://en.bookfi.net/book/1254519

Engle, R.; Granger, C. 1987. Co-integration and error correction: representation, estimation, and testing. Econometrica, Vol. 55, No. 2. pp. 251-276. http://links.jstor.org/sici?sici=0012-9682\%28198703\%2955\%3A2\%3C251\%3ACAECRE\%3E2.0.CO\%3B2-T

Girdzijauskaite, E., Radzeviciene, A., Jakubavicius, A. 2019. Impact of international branch campus KPIs on the university competitiveness: FARE method. Insights into Regional Development, 1(2), 171-180. https://doi.org/10.9770/ird.2019.1.2(7) 


\section{ENTREPRENEURSHIP AND SUSTAINABILITY ISSUES}

ISSN 2345-0282 (online) http://jssidoi.org/jesi/

2019 Volume 7 Number 2 (December)

http://doi.org/10.9770/jesi.2019.7.2(63)

Gujarati, D.N.; Porter, D.C.; Gunasekar, S.2009. Basic econometrics, The McGraw-Hill, New York, USA, http://www.econometrics.com/comdata/gujarati

Gough, S., Scott, W. Education and sustainable development: A political analysis. Educational Review - EDUC REV. 2006, 58. 273-290. https://doi.org/10.1080/00131910600748026.

Goolsbee, A. 1998. Does Government R\&D Policy Mainly Benefit Scientists and Engineers? American Economic Review, 88 (2), 298-302. https://docplayer.net/19635266-Does-government-r-d-policy-mainly-benefit-scientists-and-engineers.html

Goldfarb, Brent. 2008. The effect of government contracting on academic research: Does the source of funding affect scientific output? Research Policy, 37, 41-58. https://doi.org/10.1016/j.respol.2007.07.011

Hallinger, Philip \& Chatpinyakoop, Chatchai. 2019. A Bibliometric Review of Research on Higher Education for Sustainable Development, 1998-2018. Sustainability, 11, 2401. https://doi.org/10.3390/su11082401

Hanushek, Eric. 2016. Will more higher education improve economic growth? Oxford Review of Economic Policy, 32, 538-552. https://doi.org/10.1093/oxrep/grw025

Hasanov, Fakhri \& Mikayilov, Jeyhun I \& Yusifov, Sabuhi \& Aliyev, Khatai \& Talishinskaya, Samra. 2019. The role of social and physical infrastructure spending in tradable and non-tradable growth. Contemporary Economics, 13. https://doi.org/10.5709/ce.1897-9254.300

Hassan, Arshad \& Butt, Safdar. 2009. Impact of Ownership Structure and Corporate Governance on Capital Structure of Pakistani Listed Companies. International Journal of Business and Management, 4. https://doi.org/10.5539/ijbm.v4n2p50

Heij, Christiaan \& De Boer, Paul \& Franses, Philip \& Kloek, Teun \& Van Dijk, Herman. 2005. Econometric Methods with Applications in Business and Economics. https://global.oup.com/booksites/content/0199268010/

Hill, R. C., Griffiths, W.E., and Judge, G. G. 2001, Undergraduate Econometrics ( $2^{\text {nd }}$ Ed.). John Wiley \& Sons.Inc, United States of America. https://www.studmed.ru/hill-rc-griffiths-we-lim-gc-principles-of-econometrics_1955a5f01ae.html

Hien, D.T.T., Cho, S.E. (2018). Relationship between entrepreneurship education and innovative start-up intentions among university students. International Journal of Entrepreneurship, 22(3), 1-16. https://www.questia.com/library/journal/1G1$\underline{565734885 / \text { relationship-between-entrepreneurship-education-and }}$

Holbrook, Jack. 2019. Science Education International Meeting Challenges to Sustainable Development through Science and Technology Education. 20(1/2), 44-59. https://www.icaseonline.net/sei/files/p4.pdf

Humbatova Sugra Ingilab \& Abidi Solmaz Aghazaki.2019. The current position of science development in the world and in Azerbaijan. 5th International Conference On Lifelong Education and Leadership For All, 9-11 july, 2019 Baku, Azerbaijan, Abstract Book. https://faf348ef-5904-4b29-9cf9-98b675786628.filesusr.com/ugd/d546b1_5227dc1e0b4046eba3ae70ef0023b1fa.pdf

İbrahimova, Khayala; Suleymanov, Elchin \& Rahmanov, Farhad. 2019. Influence of Innovations on Economic Development in Azerbaijan. Academic Journal of Economic Studies, 5(3), 58-63. http://www.ajes.ro/wp-content/uploads/AJES_article_1_269.pdf

Jacob, Brian \& Lefgren, Lars. 2011. The Impact of Research Grant Funding on Scientific Productivity. Journal of public economics, 95, 1168-1177. https://doi.org/10.1016/j.jpubeco.2011.05.005.

Keane, Julie \& Allison, Janelle. 1999. The Intersection of the Learning Region and Local and Regional Economic Development: Analysing the Role of Higher Education. Regional Studies, 33, 896-902. https://doi.org/10.1080/00343409950075533.

Kwiatkowski, Denis \& Phillips, Peter \& Schmidt, Peter. 1991. Testing the Null Hypothesis of Stationarity against the Alternative of a Unit Root: How Sure Are We That Economic Time Series Have a Unit Root? Journal of Econometrics, 54, $159-178$. http://debis.deu.edu.tr/userweb/onder.hanedar/dosyalar/kpss.pdf

Fien, John. 2002. Advancing sustainability in higher education: Issues and opportunities for research. International Journal of Sustainability in Higher Education, 3, 243-253. https://doi.org/10.1108/14676370210434705. 


\section{ENTREPRENEURSHIP AND SUSTAINABILITY ISSUES}

ISSN 2345-0282 (online) http://jssidoi.org/jesi/

2019 Volume 7 Number 2 (December)

http://doi.org/10.9770/jesi.2019.7.2(63)

Frimpong, Joseph \& Oteng-Abayie, Eric Fosu. 2006. Bivariate Causality Analysis between FDI Inflows and Economic Growth in Ghana. International Research Journal of Finance and Economics, 15. https://mpra.ub.uni-muenchen.de/351/1/MPRA paper 351.pdf

Lamartina, Serena \& Zaghini, Andrea. 2011. Increasing Public Expenditure: Wagner's Law in OECD Countries. German Economic Review, 12, 149 - 164. https://doi.org/10.1111/j.1468-0475.2010.00517.x

Lane, Julia. 2009. Assessing the Impact of Science Funding. Science (New York, N.Y.). $324 . \quad 1273-1275$. https://doi.org/10.1126/science. 1175335

Lesser, Lenard \& Ebbeling, Cara \& Goozner, Merrill \& Wypij, David \& Ludwig, David. 2007. Relationship between Funding Source and Conclusion among Nutrition-Related Scientific Articles. PLoS medicine. $4 . \quad \underline{\text { e 5. }} 41-46$ https://doi.org/10.1371/journal.pmed.0040005

Liu, J, Bi, C. 2019. Effects of Higher Education Levels on Total Factor Productivity Growth. Sustainability, 11, 1790; https://doi.org/.3390/su11061790

Little, Angela \& Green, Andy. 2009. Successful globalisation, education and sustainable development. International Journal of Educational Development, 29(2), 166-174. https://doi.org/10.1016/j.ijedudev.2008.09.011

Lyakurwa, William. 2019. Human Capital and Technology for Development: Lessons for Development: Lessons for Africa. https://www.afdb.org/en/documents/document/2007-am-mr-lyakurwa-human-capital-and-technology-for-development-lessons-for$\underline{\text { africa-8276 }}$

Mackinnon, James. 1996. Numerical Distribution Functions for Unit Root and Cointegration Tests. Journal of Applied Econometrics, 11, 601-18. https://doi.org/10.1002/(SICI)1099-1255(199611)11:6<601::AID-JAE417>3.0.CO;2-T.

Muhammad, Sulaiman \& Umer, Muhammad. 2010. The Bound Testing Approach for Co-Integration and Causality between Financial Development and Economic Growth in Case of Pakistan. European Journal of Social Sciences, 13, 525-531. https://papers.ssrn.com/sol3/papers.cfm?abstract_id=2003777

Mukhtarov, Sh., Aliyev, Sh., Mikayilov, J. I., Ismayilov, A. 2019. The impact of fid on environmental degradation in Azerbaijan. 37th International Scientific Conference on Economic and Social Development -"Socio Economic Problems of Sustainable Development" - 2019, Baku, 14-15 February, 1248-1255. http://www.esd-conference.com/past-conferences

Muradov, A.J., Hasanli, Y.H., Musayeva, F. 2019. Estimation of the education influence on the population income, 37th International Scientific Conference on Economic and Social Development -"Socio Economic Problems of Sustainable Development" - 2019, Baku, 14-15 February, 592. http://www.esd-conference.com/past-conferences

Muradov, A.J., Hasanli, Y.H., Hajiyev, N.O. 2019. Assessment of the integration relationships between science and education at the doctoral. 37th International Scientific Conference on Economic and Social Development -"Socio Economic Problems of Sustainable Development" - 2019, Baku, 14-15 February, 592. http://www.esd-conference.com/past-conferences

Nevin, E. 2008. Education and sustainable development. Policy \& Practice: A Development Education Review, 6, Spring, pp. 49-62. https://www.developmenteducationreview.com/issue/issue-6/education-and-sustainable-development

Ogujiuba, Kanayo \& Adenuga, Adeniyi. 2005. Economic growth and human capital development: the case of Nigeria. https://econwpa.ub.uni-muenchen.de/econ-wp/mac/papers/0508/0508023.doc

Payne, A. \& Siow, Aloysius. 2003. Does Federal Research Funding Increase University Research Output? Advances in Economic Analysis \& Policy, 3(1), 1-24. https://doi.org/10.2202/1538-0637.1018.

Pesaran, Hashem \& Smith, Richard \& Shin, Yongcheol. 2001. Bound Testing Approaches to the Analysis of Level Relationship. Journal of Applied Econometrics, 16, 289-326. https://doi.org/10.1002/jae.616.

Pesaran, M. Hashem, Yongcheol Shin 1999. An autoregressive distributed lag modeling approach to cointegration analysis / Econometrics and Economic Theory in the 20th Century: The Ragnar Frisch centennial Symposium, Cambridge University Press, Cambridge. 371-413. https://doi.org/10.1017/CCOL521633230.011. 


\section{ENTREPRENEURSHIP AND SUSTAINABILITY ISSUES}

ISSN 2345-0282 (online) http://jssidoi.org/jesi/ 2019 Volume 7 Number 2 (December)

http://doi.org/10.9770/jesi.2019.7.2(63)

Pesaran, H. M., Pesaran, B. 1997. Working with Microfit 4.0: Interactive Econometric Analysis; [DOS and Windows version]. Oxford University Press. With B. Pesaran, Working with Microfit 4.0: Interactive Econometric Analysis, (DOS and Windows versions), Oxford University Press, pp.511.

Resnik. David B. 2007. The Price of Truth: How Money Affects the Norms of Science (Practical and Professional Ethics.) xiii + 224 pp., bibl., index. Oxford: Oxford University Press, https://socionet.ru/publication.xml?h=repec:cup:ecnphi:v:24:y:2008:i:01:p:123$\underline{129 \_00}$

Elchin Suleymanov; Anar Eminov; Yadulla Hasanli \& Anar Mirzayev. 2018. The Role of Education in Organization and Development of Economics in Azerbaijan. Academic Journal of Economic Studies, 4(2), 45-50. http://www.ajes.ro/wpcontent/uploads/AJES_article_1_168.pdf

Sun, B., Ning, X., University, Q. 2016. The value and significance of education modernization for the construction of livable and happy city-the case study of Qingdao. The Review of Higher Education Journal, 12, 16-23. http://en.cnki.com.cn/Article_en/CJFDTotal-LGJY201612002.htm

Sjöström, Jesper \& Rauch, Franz \& Eilks, Ingo. 2015. Chemistry Education For Sustainability. In I. Eilks \& A. Hofstein (Eds.), Relevant chemistry education - From theory to practice. Rotterdam: Sense in print. https://doi.org/110.1007/978-94-6300-175-5_9.

Slottje, Daniel. 2010. Human capital measurement: Theory and practice. Journal of Economic Surveys. 24. 201-205. https://doi.org/10.1111/j.1467-6419.2009.00612.x.

Stephens, Jennie \& Hernandez, Maria \& Román, Mikael \& Graham, Amanda \& Scholz, Roland. 2008. Higher education as a change agent for sustainability in different cultures and contexts. International Journal of Sustainability in Higher Education, 9. https://doi.org/10.1108/14676370810885916.

Stephan, P. 2012. Harvard University Press, Cambridge, Massachusetts (2012), 384 p. Sociologie du Travail. 56. https://doi.org/10.1016/j.soctra.2013.12.014

Tianqi, W., Lijun, H. 2018, An Empirical Study on the Relationship between Agricultural Science and Technology Input and Agricultural Economic Growth Based on E-Commerce Model. Sustainability, 10, 4465; https://doi.org/10.3390/su10124465

Tvaronavičienè, Manuela \& Tarkhanova, Elena \& Durglishvili, Nino. 2018. Sustainable economic growth and innovative development of educational systems. Journal of International Studies. 11. 248-256. https://doi.org/10.14254/2071-8330.2018/11-1/19.

Tvaronavičienė, M., Shishkin, A., Lukáč, P., Illiashenko, N., \& Zapototskyi, S. 2017. Sustainable economic growth and development of educational systems. Journal of $\quad$ International $\quad$ Studies, 10(3), $285-292$. https://www.jois.eu/files/20_423_Tvaronaviciene\%20et\%20al.pdf

Vedder, Richard. 2004. Going Broke by Degree: Why College Costs Too Much. American Enterprise Institute for Public Policy Research. 1150 Seventeenth Street NW, Washington, DC 20036. http://www.aei.org

Wals, Arjen. 2013. Sustainability in higher education in the context of the UN DESD: a review of learning and institutionalization processes. Journal of Cleaner Production 62(1), 8-15. https://doi.org/10.1016/j.jclepro.2013.06.007 https://doi.org/10.1016/j.jclepro.2013.06.007

Wagner, Alan. 1996. Financing Higher Education: New Approaches, New Issues. Higher Education Management, 8(1), 7-17. https://eric.ed.gov/?id=EJ523039

Wals, A. 2009. Review of Contexts and Structures for Education for Sustainable Development: Learning for a Sustainable World. UNDESD 2005-2014. UNESCO, Paris, France. https://unesdoc.unesco.org/ark:/48223/pf0000184944

Ware, Sylvia. 2001. Teaching chemistry from a societal perspective. Pure and Applied Chemistry - PURE APPL CHEM. 73. 12091214. https://doi.org/10.1351/pac200173071209.

Whalley, Alexander \& Hicks, Justin. 2014. Spending wisely? How resources affect knowledge production in universities. Economic Inquiry, 52, 35-55. https://doi.org/10.1111/ecin.12011.

Wolff, Edward. 2001. The Role of Education in the Postwar Productivity Convergence among OECD Countries. Industrial and Corporate Change, 10, 735-59. https://doi.org/10.1093/icc/10.3.735. 


\section{ENTREPRENEURSHIP AND SUSTAINABILITY ISSUES}

ISSN 2345-0282 (online) http://jssidoi.org/jesi/

2019 Volume 7 Number 2 (December)

http://doi.org/10.9770/jesi.2019.7.2(63)

Wilbanks, John \& Wilbanks, Thomas. 2010. Science, Open Communication and Sustainable Development. Sustainability, 2, 993-1015. https://doi.org/10.3390/su2040993.

Yuan, Xueliang \& Zuo, Jian. 2013. A critical assessment of the Higher Education for Sustainable Development from students' perspectives - a Chinese study. Journal of Cleaner Production. 48. 108-115. https://doi.org/10.1016/j.jclepro.2012.10.041.

Zilahy, Gyula \& Huisingh, Donald. 2009. The roles of academia in Regional Sustainability Initiatives. Journal of Cleaner Production, 17. 1057-1066. https://doi.org/10.1016/j.jclepro.2009.03.018.

Zhou, Guangyou \& Luo, Sumei. 2018. Higher Education Input, Technological Innovation, and Economic Growth in China. Sustainability, 10, 2615. https://doi.org/10.3390/su10082615

Sugra HUMBATOVA is the PhD in Econ., 1. Department of Economy and Management, International Center for Graduate Education, Azerbaijan State University of Economics (UNEC). 2. Department of World Economy, Baku Engineering University (BEU). Research interests: pricing; microeconomics; macroeconomics.

ORCID ID: 0000-0002-9380-941X

Natig HAJIYEV is the PhD in Econ., senior lecturer of department "Regulation of economy" of Azerbaijan State University of Economics (UNEC). Research interests: history of economic doctrines; macroeconomics; inflation. ORCID ID: 0000-0003-3155-2708

ORCID ID: orcid.org/0000-0002-9667-3730

Register for an ORCID ID:

https://orcid.org/register

Copyright (C) 2019 by author(s) and VsI Entrepreneurship and Sustainability Center

This work is licensed under the Creative Commons Attribution International License (CC BY).

http://creativecommons.org/licenses/by/4.0/

c) (i) Open Access 